\title{
THE GENITAL DUCTS OF SOME BRITISH STENOGLOSSAN PROSOBRANCHS
}

\author{
By Vera Fretter, Ph.D. \\ Departments of Zoology, Birkbeck and Royal Holloway Colleges, \\ University of London
}

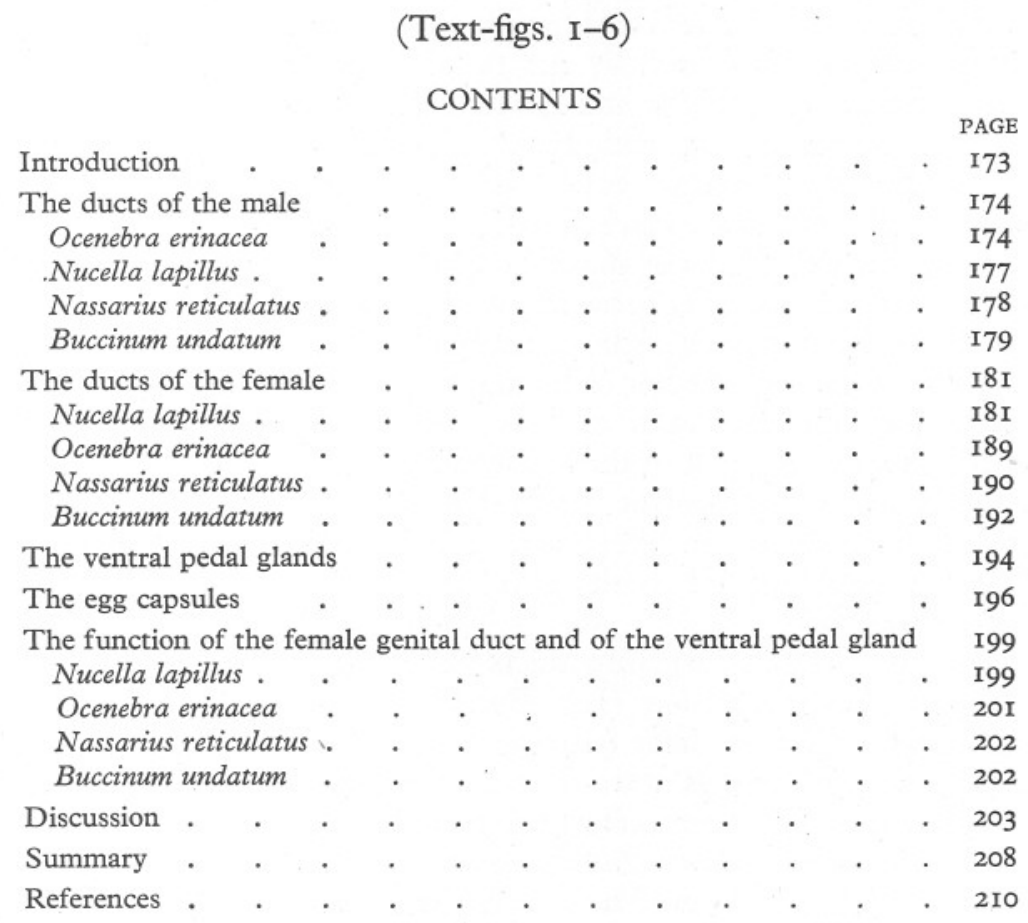

\section{INTRODUCTION}

It has long been known that in the stenoglossan Prosobranchia the ventral pedal gland plays some part in the formation of the egg capsule, but the exact functions of the various parts of the genital ducts have not hitherto been investigated. The ventral pedal gland was originally taken to be the external opening of a water vascular system, and Carrière (I882) was the first to show that this structure was really a gland. Cunningham (I899) ascribed to it the function of producing the chitinous capsules around the eggs which had been passed into it from the oviduct in Buccinum and Murex (=Ocenebra), and of fixing them to the substratum. Simroth (I896-1907) after first agreeing with this opinion ultimately concluded that the capsules were formed in the oviduct and then passed to the pedal gland. His theory was originally rejected by 
Pelseneer (I9I0), who found capsules in the pedal gland of Purpura $(=$ Nucella $)$ lapillus which, owing to their thin, transparent, colourless walls, so unlike the final product, suggested that secretion from the gland was responsible for forming them; this view was quoted by Thiele (1925). Later, however, Pelseneer (1926) obtained capsules from the terminal region of the oviduct of Nassa (= Nassarius) reticulata, which proved that the origin of the capsule must be sought in the genital ducts, though the pedal gland may complete its moulding and harden it. Three years later Ankel (1929) in his observations on $N$. mutabilis and $N$. reticulata compared egg capsules taken from the oviduct with those completed by the pedal gland, and proved conclusively that the gland merely moulds and hardens the secretion which is laid down around the egg mass in the genital ducts. Ankel (1929, 1935, 1937) further suggested that the two sutures easily visible on the surface of the egg case of N. mutabilis, $N$. reticulata, Nucella lapillus and also of Lamellaria perspicua were due to the fact that the ducts in which the capsules are secreted are bilobed. Ankel's conclusions agree in every detail with the observations here described, but his papers include no study of the local manufacturing of the various parts of the egg case nor of the manœuvring of eggs and sperm within the ducts. A complete account of the structure and function of the genital ducts of both sexes is given in the following pages.

The work was carried out at Birkbeck College, Royal Holloway College, and the Plymouth Marine Laboratory. I wish to express my thanks to the University of London and to the British Association for the use of their tables at Plymouth.

The animals of which the genital ducts were investigated included Ocenebra erinacea (L.), Nucella lapillus (L.), Buccinum undatum L., Nassarius reticulatus (L.) and N. incrassatus (Ström), using the names given by Winckworth (1932). The animals were examined alive by means of a binocular microscope. The tissues were difficult to manipulate owing to their extremely glandular nature, and it was found best to fix them in Susa and Keilin's (I92I) modification of Bouin. The distribution of different types of glands in the duct was most easily demonstrated by staining the whole structure in an alcoholic solution of thionin.

\section{The Ducts of The Male \\ Ocenebra erinacea}

From the testis, situated on the columellar side of the visceral mass, the coiled vas deferens passes anteriorly in a superficial position. It leads beneath the gut and the pericardium to the right posterior corner of the mantle cavity and here opens into the prostate gland. The latter runs parallel with the rectum to the opening of the mantle cavity and from it a narrow duct passes along the right side of the head to the penis, which lies behind the right tentacle. On account of histological and physiological differences the duct 
leading to the prostate is divisible into two regions-a long coiled posterior part, which in the breeding season is distended with sperm, thus functioning as a vesicula seminalis, and short straight ciliated part leading beneath the intestine and the pericardium to the prostate, and separated from the vesicula seminalis by a sphincter. The two regions correspond to the vesicula seminalis and the vas deferens described by Linke (1933) in Littorina littorea, L. obtusata and $L$. rudis, and there is close agreement also in histological detail. In the vesicula seminalis the epithelium consists of columnar ciliated cells resting upon a basement membrane, beneath which a few circular muscles are developed. The basal nuclei of the columnar cells are spherical or irregular in outline, each with a nucleolus, and above them the cytoplasm is vacuolated. During the breeding season at least, many of the vacuoles contain lightly staining spherules, whereas in others ingested sperm may be found, for, as in the species of Littorina previously mentioned, the vesicula seminalis serves as an area for sperm absorption. The absorbed sperm are digested and the spherules may be regarded as their breakdown products. Relaxation of the sphincter at the entrance to the lower part of the duct, the true vas deferens, allows the contents of the vesicula seminalis, in which the sperm are under pressure, to pass to the prostate. The movement of sperm through the vas deferens is assisted by the thick layer of cilia borne by the columnar epithelial lining. The cilia arise from basal granules, and from these intracellular fibrillae run deeply into the cytoplasm. The epithelium is surrounded externally by circular muscles which are more numerous than in the vesicula seminalis. Close to its opening into the prostate the vas deferens gives off a short diverticulum towards the pericardium, and the blind end of the diverticulum is connected with a slight prominence on the pericardial wall by a band of dense connective tissue and muscle fibres. This strand reaches the pericardial wall close to the renopericardial aperture and lies in a comparable position to the gonopericardial duct of the female. In Littorina, Linke (1933) describes a similar connective tissue strand passing from the vas deferens to the pericardium though no diverticulum is mentioned. In Calyptraea sinensis (Giese, I9I5), animals changing from male to female develop a gonopericardial duct, and this first appears as a strand of dense mesenchyme bridging the gap between the vas deferens and the pericardium. It therefore appears that in the male of Ocenebra erinacea this is the remnants of a gonopericardial duct.

The lateral walls of the prostate (Fig. I) are thickened by a profuse development of glands (CGC) beneath the ciliated epithelium (CE), and in transverse section the lumen (L) appears as an extensive longitudinal slit between these lobes. The vas deferens leads to the narrow ventral surface of the gland and its entrance is guarded by a sphincter. If the mantle cavity of Ocenebra be opened to display the prostate it will be seen that the gland communicates with the posterior extremity of the mantle cavity by a slit-like aperture along the thin ventral wall. The aperture lies between two projecting flaps of tissue which in front of it fuse and are continued along the length of the ventral 
surface of the gland as a slight ridge. Sections show that the projecting lips of the orifice are ventral extensions of the epithelial lining of the prostate beneath which no glands are present, and anteriorly they are joined one to the other to close the prostate (FE) and to form the projecting ridge. In Littorina the prostate is composed of two similar lateral glandular lobes, but it is open throughout its length along the ventral surface. Thus Ocenebra demonstrates the formation of a closed prostate from the open type of Littorina, and the opening into the mantle cavity is due to the incomplete fusion of the two lobes. The significance of this opening will be dealt with later. In the vicinity of the opening the cilia beat into the prostate, at right angles to the aperture. Elsewhere in the gland they cause an anteriorly directed current.

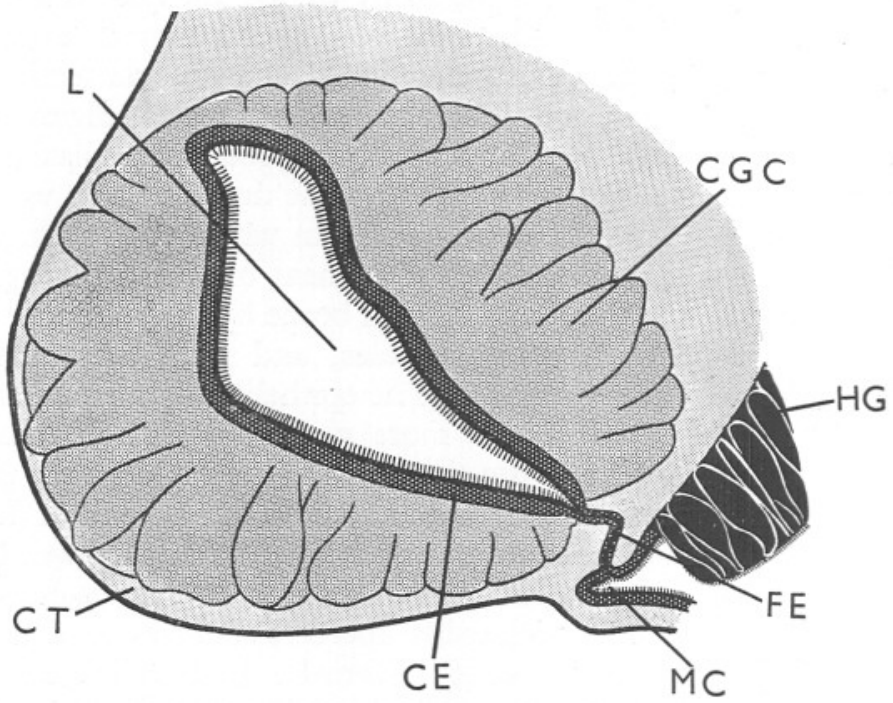

Fig. I. Ocenebra erinacea. Transverse section through the prostate: camera lucida drawing $(\times 56)$.

CE, ciliated epithelium; CGC, cluster of subepithelial gland cells; CT, connective tissue; FE, epithelia which fuse to close the prostate; HG, hypobranchial gland; L, lumen of prostate; MC, mantle cavity.

The subepithelial gland cells of the prostate are grouped in spherical clusters (CGC), the ducts from a single cluster running parallel with one another to open between the ciliated cells. Each gland cell has a round basal nucleus with a prominent nucleolus. The cytoplasm is packed with granules which stain lightly with iron haematoxylin, except those around the nucleus which stain more densely. After azan the contents are yellowish in the vicinity of the nucleus and in the upper parts of the cell varying shades of purple. The azan stain shows that between these gland cells are scattered mucous cells. The columnar ciliated cells are compressed laterally by the ducts of the glands; their elongated nuclei lie towards the centre of the cytoplasm. The 
cilia arise from basal granules, and intracellular fibrillae pass from these into the deeper regions of the cell, which also contains numerous granules. In the region of fusion between the two ventral lips of the prostate the cells of one side are in close contact with those of the other and no trace of cilia can be seen between, so that, in transverse section, a double row of cells appears to lead from the lumen to the mantle cavity (FE). These cells are cubical, with spherical nucleolated nuclei in the centre of the cytoplasm. At the opening into the mantle cavity the two sheets of epithelium separate; their cells become tall and columnar, like the cells lining the prostate which they resemble in all other features. Among them are a few mucous cells.

From the ventral surface of the prostate arises the ciliated tube which runs up the right side of the head to the penis. In Littorina this duct is represented by a deep groove running along a raised muscular ridge, and the edges of the groove can be brought close together to form a closed channel. In Ocenebra the edges have fused to form a tube, and evidence of this fusion is seen in sections by the two joined strips of epithelium, which are continuous with those of the prostate and lead from the lumen to the exterior. They are thrown into longitudinal folds and possess the same histological structure as in the previous region. In like manner the channel leading up the penis to its tip has been closed in Ocenebra, whereas it is open in Littorina.

The duct to the penis runs up the side of the head along a slight ridge which a layer of transverse muscles separates from the underlying tissues. The epithelium is thrown into longitudinal folds owing to the differences in the heights of the columnar ciliated cells of which it is composed. The nuclei are round, oval or irregular and lie towards the middle of the cells which, distally, contain granules; intracellular fibrillae pass from the basal granules of the cilia to the region of the nuclei. Beneath the basement membrane is a welldeveloped layer of circular muscles.

The penis is slightly flattened dorsoventrally and its duct is not centrally placed, but lies towards the outer edge. The histological structure of the epithelium is similar to that of the preceding duct; no gland cells are present. At its tip the two layers of fused epithelia separate to form the penial aperture. A layer of circular muscles lies beneath the epithelium of the duct and extends beneath the fused strips of epithelium. Throughout the thickness of the penis muscle fibres penetrate the connective tissue-longitudinal muscles run from base to tip, a layer of circular muscles runs under the outer epithelium, and beneath these dorsoventral and oblique muscles are developed. Blood spaces are numerous and the penial nerve occupies a central position.

\section{Nucella lapillus}

The gross morphology of the male reproductive system of Nucella lapillus is similar to that of Ocenebra erinacea, and between the two there is a close correspondence in histological detail. Only the few points in which they differ will be mentioned. In the short vas deferens, which leads from the vesicula 
seminalis to the prostate, no trace of a gonopericardial duct can be found, and the muscles underlying the vas deferens are more strongly developed than in Ocenebra. The prostate is smaller and the spherules filling its gland cells, of which there is only one type, stain lightly with mucicarmine and blue with azan. The opening of the prostate into the mantle cavity is reduced to a minute aperture, and along the whole length of the genital duct anterior to this point can be seen the two strips of epithelium which fuse to close it. That part of the duct which runs from the prostate up the right side of the head to the penis has, underlying it, a thicker layer of circular muscles, and the penis is more dorsoventrally flattened than in Ocenebra.

\section{Nassarius reticulatus}

The structure of the male genital duct of Nassarius reticulatus differs in some essential features from that of Ocenebra or Nucella. The upper part of the vas deferens is greatly coiled and functions as a seminal vesicle; in the breeding season it can be traced below the surface of the visceral mass distended with sperm. The epithelium resembles that of Ocenebra: in like manner it is capable of ingesting sperm from the lumen. The true vas deferens is a straight duct which leads to the upper extremity of the mantle cavity on the right side, and rarely contains sperm except during the time of copulation. It is separated from the preceding region by a sphincter, and throughout its course a thick coat of circular muscles underlies the columnar ciliated epithelium which lines it. A slight thickening in the connective tissue between the vas deferens and the pericardium suggests the remains of a gonopericardial duct.

From the vas deferens the genital duct leads forward along the right side of the mantle cavity; its course is approximately parallel to that of the rectum. At the opening of the cavity it passes up the right side of the head to the penis. In Ocenebra the posterior region, traversing the length of the mantle cavity, is represented by the prostate. It has a much enlarged lumen and thick glandular walls, and the anterior region is a narrow ciliated duct. In Nassarius no such differentiation occurs, and from the vas deferens to the penis the duct is narrow, of about the same diameter as the former, and is of uniform histological structure-it is lined by an epithelium of gland cells alternating with ciliated cells and no subepithelial glands occur. The opening of the vas deferens into this anterior glandular region, the whole of which may be termed the prostate, is marked by a projecting circular fold of ciliated epithelium, and a sphincter is capable of closing the aperture completely. From this point, at the posterior extremity of the prostate, a short ciliated duct leads to the mantle cavity and, on dissection, its opening can be seen between the anterior margin of the kidney and the genital duct. It corresponds to the slit-like opening of Ocenebra. The duct has thick muscular walls and its external opening may be closed by a sphincter. Anterior to it the genital tract has no connexion with the mantle cavity, and there is no indication of its formation from an open groove as in Ocenebra. 
Throughout its length the prostate is surrounded by a thick layer of circular muscles, and during copulation the spermatozoa are conveyed with great rapidity along it by peristalsis aided by the cilia. The gland cells which alternate with the ciliated cells of the epithelium have highly vacuolated protoplasm. The vacuoles contain spherules which tend to dissolve on fixation, but which stain lightly with iron haematoxylin and pale blue with azan. The spherical nuclei, each with a prominent nucleolus, lie towards the base of the cytoplasm. The cilia arise from basal granules and from these intracellular fibrillae can be traced to the central region of the cell. Minute orange or yellow pigment granules are scattered in the distal half of each cell and the oval nuclei lie towards the base. That part of the duct which runs up the side of the head to the penis is situated on a slight ridge, and this is separated from the underlying tissues by a sheet of transverse muscles.

The penis is flattened dorsoventrally and its duct is central. The histological character of the lower part of the duct is exactly similar to that of the prostate, but towards the mid region the gland cells disappear, and distally the duct is lined by a columnar ciliated epithelium with cells of uniform height. As in the preceding region of the genital tract a thick layer of circular muscles underlies the epithelium, and spermatozoa are conveyed to the terminal opening by peristalsis and ciliary action. In the subepithelial connective tissue of the terminal part of the duct there are numerous mucous cells, their necks passing between the ciliated cells. The musculature of the penis differs from that of Ocenebra: beneath the external epithelium is an outer layer of circular and oblique muscles and an inner layer of longitudinal fibres, and well-developed blood spaces run laterally through the length of the penis. The central region, containing the duct with its thick muscular coat, the penial nerve and other blood spaces, is separated from the outer region by a layer of circular muscles, and dorsoventral muscles penetrate every part of the connective tissue.

\section{Buccinum undatum}

The male genital duct of Buccinum undatum (Fig. 2) resembles most closely that of Nassarius reticulatus. The coiled posterior part of the vas deferens acts as a vesicula seminalis (vs). It is covered by a ciliated epithelium and the cytoplasm of the cells is vacuolated. The distal vacuoles may contain ingested sperm, and in others may be seen brownish granular concretions which, as in Ocenebra, are probably the products of sperm digestion. A thick muscular coat is developed below the basement membrane and this consists of an inner circular layer and outer longitudinal fibres. The duct straightens just before it enters the posterior end of the mantle cavity and the musculature increases in thickness. This short region which passes to the mantle cavity is the true vas deferens (VD), into which the sperm are liberated during the breeding season and through which they are passed mainly by muscular activity. Ventral to the kidney aperture the vas deferens opens into a thicker region of the genital duct (PR), which passes forward along the right side of the body, 
beneath the rectum $(\mathrm{R})$, and projects from the surface of the floor of the mantle cavity as a prominent ridge. At the mouth of the cavity it passes dorsally to the base of the penis (P) which is situated on the right side of the neck. The region of the duct which passes through the mantle cavity to the penis is of about the same diameter throughout, although there appears fairly constantly

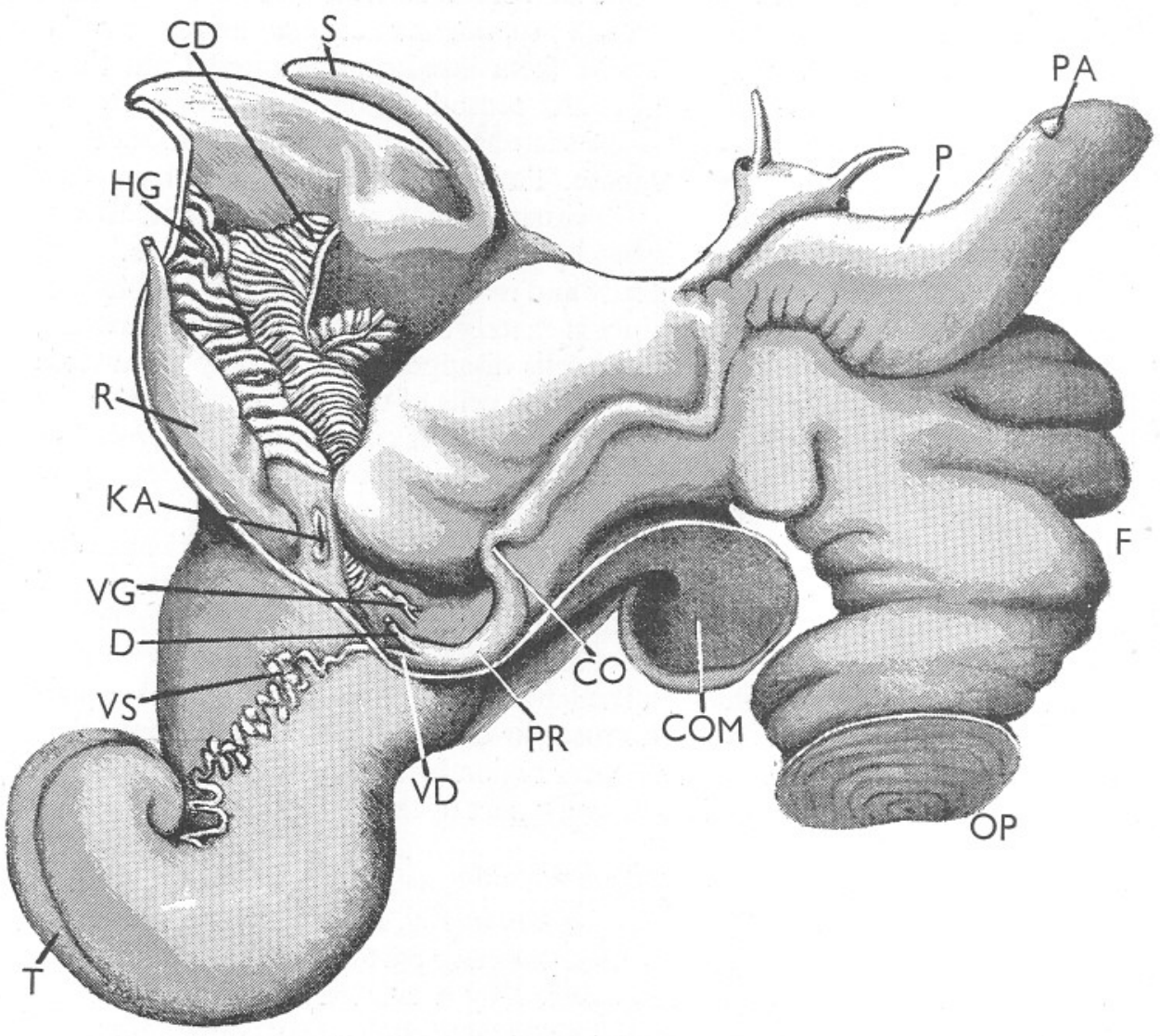

Fig. 2. Buccinum undatum. Dissection to display the male genital duct, the mantle cavity having been opened along the right side ( $\times$ about $\left.I \frac{t}{8}\right)$.

$\mathrm{COM}$, columellar muscle; $\mathrm{CO}$, constriction; $\mathrm{CD}$, ctenidium; $\mathrm{D}$, duct leading from the prostate to the mantle cavity; F, foot; HG, hypobranchial gland; KA, aperture of kidney; OP, operculum; P, penis; PA, papilla; PR, prostate; $R$, rectum; s, siphon; T, testis; VD, vas deferens; VG, visceral ganglion; vS, vesicula seminalis.

a constriction (co) just about the point where the duct passes on to the side wall of the proboscis sheath.

If the mantle cavity of a male Buccinum be opened to expose the prostate (Fig. 2) it will be seen that from the posterior end of this gland and on the left side there arises a narrow duct (D). This passes backwards and to the left to open to the mantle cavity. The opening is alongside the visceral ganglion. 
The presence of this structure was not mentioned by Dakin (I9I2) in his description of the male genital system. It is lined by a columnar ciliated epithelium in which mucous glands are scattered. Beneath the epithelium is a very thick layer of circular and longitudinal muscles. The opening of the vas deferens into the prostate is situated on a small papilla immediately anterior to the opening of the duct. Internally the walls of the prostate are folded longitudinally and covered by a columnar ciliated epithelium. A layer of circular muscles, $200 \mu$ thick, underlies the basement membrane, and between the muscles pass the ducts of a still deeper layer of gland cells. The glands are of two types. In one the cytoplasm is filled with small spherules which stain lightly with iron haematoxylin and red with azan. The nuclei are spherical and each has a prominent nucleolus. The second type of cell is a mucous cell. The ducts are long, exceeding $300 \mu$, and they pass between the epithelial cells to open into the lumen of the gland. During the breeding season, when the gland is well developed, the distal tips of the ducts are swollen with secretion and compress the ciliated cells. Circular and oblique muscle fibres pass between the glands and surround the prostate externally.

The duct which passes through the large flattened penis ( $P$ ) opens at the apex of a papilla (PA) which is subterminal and on its upper edge. The duct is lined by a columnar ciliated epithelium and surrounded by a thick layer of circular muscle. About the middle of the penis the duct measures only $180 \mu$ in diameter, but towards the papilla it is further reduced to a very fine tube and the thickness of the muscular coat is correspondingly decreased.

\section{The Ducts of the Female}

\section{Nucella lapillus}

Owing to the ease of obtaining material the female genital system and the formation of the egg capsules has been studied in greater detail in Nucella lapillus (Figs. 3, 4, 5a and 6) than in Ocenebra erinacea.

The ovary (Fig. 3, o) spreads over the surface of the digestive gland in the visceral mass, and from it a thin-walled oviduct (Figs. 3, 4, OD) leads forwards and ventrally on the right side of the viscera. The anterior region can be seen through the integument and has the appearance of a large blood vessel. At a point below the kidney it opens into the albumen gland (Fig. 3, AG) which turns abruptly dorsalwards, making an acute angle with the oviduct, and then recoils on itself passing ventrally to open into the capsule gland (Figs. 3, 4, $\mathrm{OAC})$. At the junction of the oviduct with the albumen gland arises the gonopericardial duct. The capsule gland leads forward on the right side of the mantle cavity and, on dissection, it can be seen as an opaque white or yellowish mass which is divided into right and left glandular lobes (Figs. 3, 4, RLC, LLC). These lobes are joined dorsally and ventrally by a comparatively thin and narrow wall forming a dorsal and ventral suture, so that in transverse section the lumen of the gland has the appearance of a dorsoventral slit (Fig. 5a, L). 
From the narrow ventral wall, where gland cells are absent, arise two longitudinal folds of tissue (Figs. 4, 5a, RL, LL). These form between them a longitudinal channel (Fig. $5 a, \mathrm{vC}$ ). The left longitudinal fold (LL) is better developed than the right (RL), over which it bends and which it may completely envelop. Thus the ventral channel may be closed off from the lumen of the capsule gland and form a functionally closed duct. Posteriorly the channel leads through a short duct (Fig. 4, DIG) to a deep brown glandular mass situated between the capsule and albumen glands. This is the ingesting gland (Fig. 3, IG) and its narrow duct is surrounded by a thick muscular coat. The albumen gland opens into the posterior ventral wall of the capsule gland on the right side of

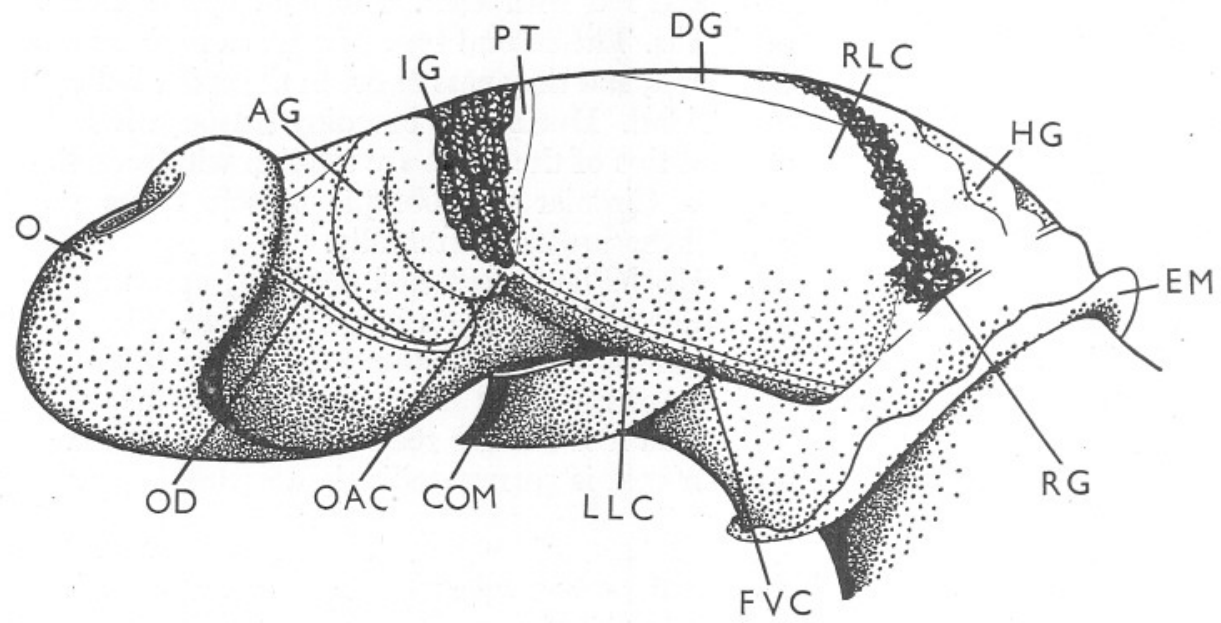

Fig. 3. Nucella lapillus. Visceral hump seen from the right side after the removal of the shell $(\times 6)$.

AG, albumen gland; COM, columellar muscle; DG, gland cells of the dorsal wall of the capsule gland; EM, free edge of mantle; FVC, floor of ventral channel; HG, hypobranchial gland; IG, ingesting gland; LLC, left lobe of capsule gland; O, ovary; OAC, opening of albumen gland into capsule gland; OD, oviduct; PT, posterior tip of capsule gland; RG, rectal gland; RLC, right lobe of capsule gland.

the ventral channel (Fig. 4, OAC). Anteriorly the capsule gland opens into a muscular vestibule (v), and through this the ventral channel leads into the bursa copulatrix (BC), which when filled with sperm bulges into the vestibule. The short vagina (VA), into which the penis is inserted to deposit sperm in the bursa, and from which the fully formed egg capsules pass from the vestibule to the exterior, opens on the right anterior extremity of the mantle cavity, ventral to the anus; the opening is surrounded by a sphincter.

As the oviduct approaches the albumen gland its glandular lining is replaced by a columnar ciliated epithelium, thrown into longitudinal folds by variations in the thickness of the underlying connective tissue. A similar epithelium is found in the gonopericardial duct. This opens into the pericardium by an inconspicuous ciliated funnel, and beneath the basement 


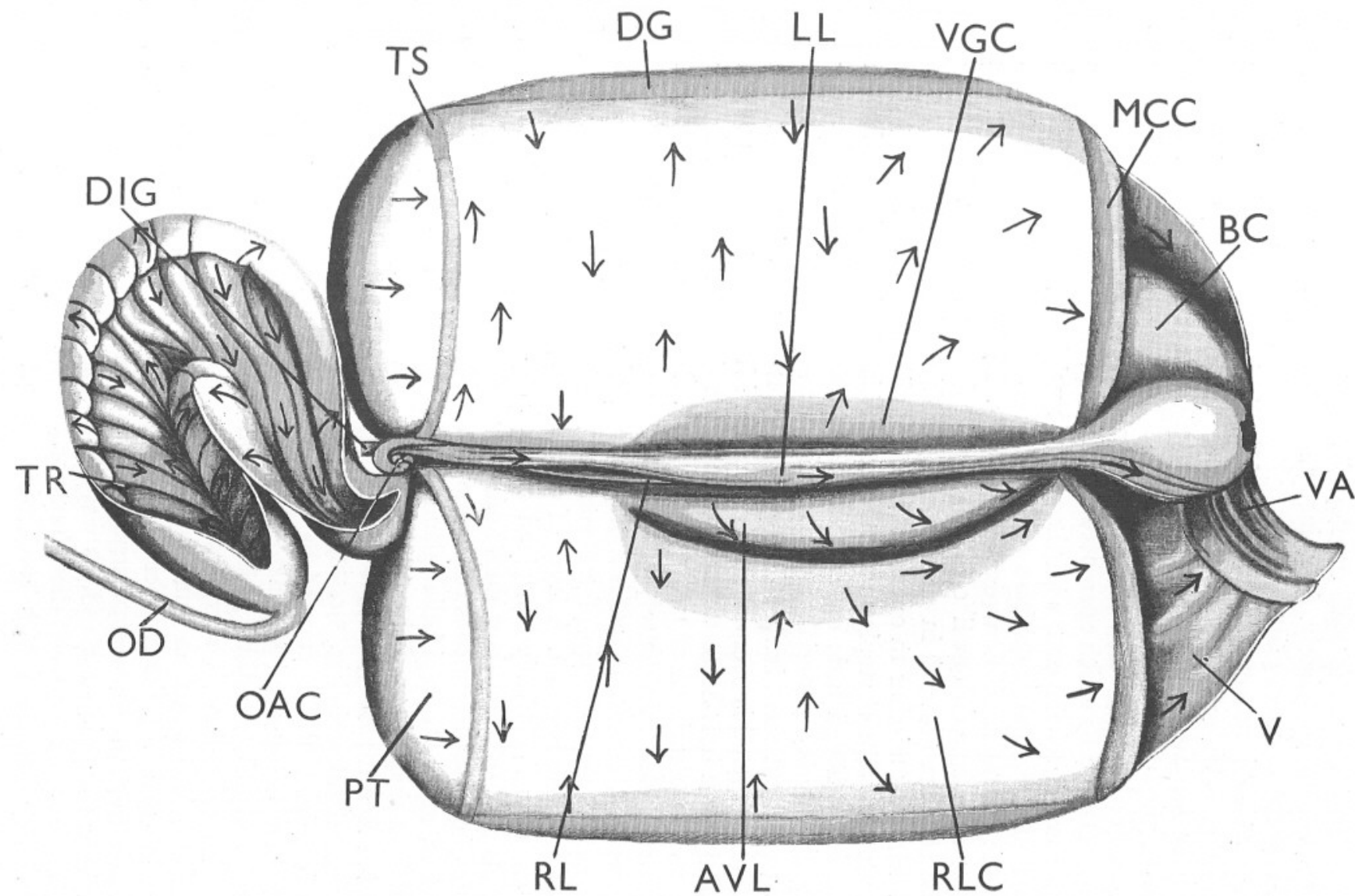

Fig. 4. Nucella lapillus. The female genital duct. The muscular vestibule and the capsule gland have been opened by a dorsal longitudinal incision and the albumen gland by a longitudinal incision along the right side. Arrows show ciliary currents. $(\times$ about 12$)$ AVL, anteroventral lobe of capsule gland; BC, bursa copulatrix; DIG, duct of ingesting gland; LL, left longitudinal fold; MCC, mucous cells of the anterior border of the capsule gland; RL, right longitudinal fold; TR, transverse ridges on the wall of the albumen gland; TS, transverse muscular strips; v, vestibule; VA vagina; VGC, anteroventral gland cells. Other letters as in Fig. 3. 
membrane of the epithelium are circular and scattered longitudinal muscle fibres; the musculature is well developed around the pericardial opening which it may close completely. A sphincter also surrounds the opening of the oviduct into the albumen gland.

When the shell is removed from a living Nucella the opaque, white albumen gland (Fig. 3, AG) is seen through the integument. It is laterally compressed and its walls are ridged transversely (Fig. 4, TR), owing to variations in the thickness of the subepithelial glandular tissue. The gland is ciliated throughout: ciliated cells line the lumen and these are constricted by the ducts of the underlying gland cells which open between them, and by epithelial gland cells which in some parts alternate with them. The nuclei of the ciliated cells are elongated and lie towards the base of the cytoplasm, or they may be pushed towards the distal end of the wedge-shaped cells. Living material shows that the gland cells contain small colourless spherules or granules. The subepithelial cells are grouped in clusters and the ducts from each cluster run parallel with one another to open between the ciliated cells. The nuclei lie towards the base of the cytoplasm and are oval or circular in outline, each with a nucleolus. Although little differentiation between the glands can be distinguished in living material, sections demonstrate the presence of three distinct types, and these have a fairly constant distribution. The outer wall of the albumen gland is composed only of cells with granular contents which stain lightly with iron haematoxylin and mucicarmine, whereas the inner or median wall is composed of two types of cells. In one of these the small secretory spherules stain densely with iron haematoxylin and are unaffected by mucicarmine, and the second less plentiful type is mucus-secreting. These cover a narrow ventral strip of the median wall, though some may have a more scattered distribution. A layer of circular muscles is developed in the connective tissue. The albumen gland opens on to the ventral wall of the capsule gland (OAC) by a short duct lined by a columnar ciliated epithelium with a few interspersed mucous cells. The cilia are long, exceeding the height of the cells, and no subepithelial gland cells are present. The duct is surrounded by a thick layer of circular muscles, which on contraction close the passage between the two glands.

The ventral channel (Fig. 5a, vc), which leads posteriorly from the bursa copulatrix (Fig. 4, BC), is covered by a columnar unciliated epithelium. To the cells may be attached spermatozoa, closely packed together with their heads embedded in the distal protoplasm and their tails projecting into the lumen. The epithelium is surrounded externally by a thin inner layer of longitudinal muscles and an outer circular layer; this musculature enables sperm to be passed up the channel by peristalsis. In Littorina (Linke, I933) sperms pass from the bursa copulatrix to the receptaculum seminis, which is embedded in the albumen gland, by way of two longitudinal folds. A ciliary current on the under surface of these transports the sperm balls. Longitudinal folds similarly concerned with conducting seminal fluid are described in 
Viviparus bengalensis by Annandale and Sewell (192I). At the posterior end of the capsule gland the ventral channel leads into a duct (Fig. 4, DIG) which passes to the ingesting gland (Fig. 3, IG). The walls of the duct are folded longitudinally and surrounded by a very thick layer of circular muscles, and masses of sperm are invariably attached to the columnar epithelial lining. In
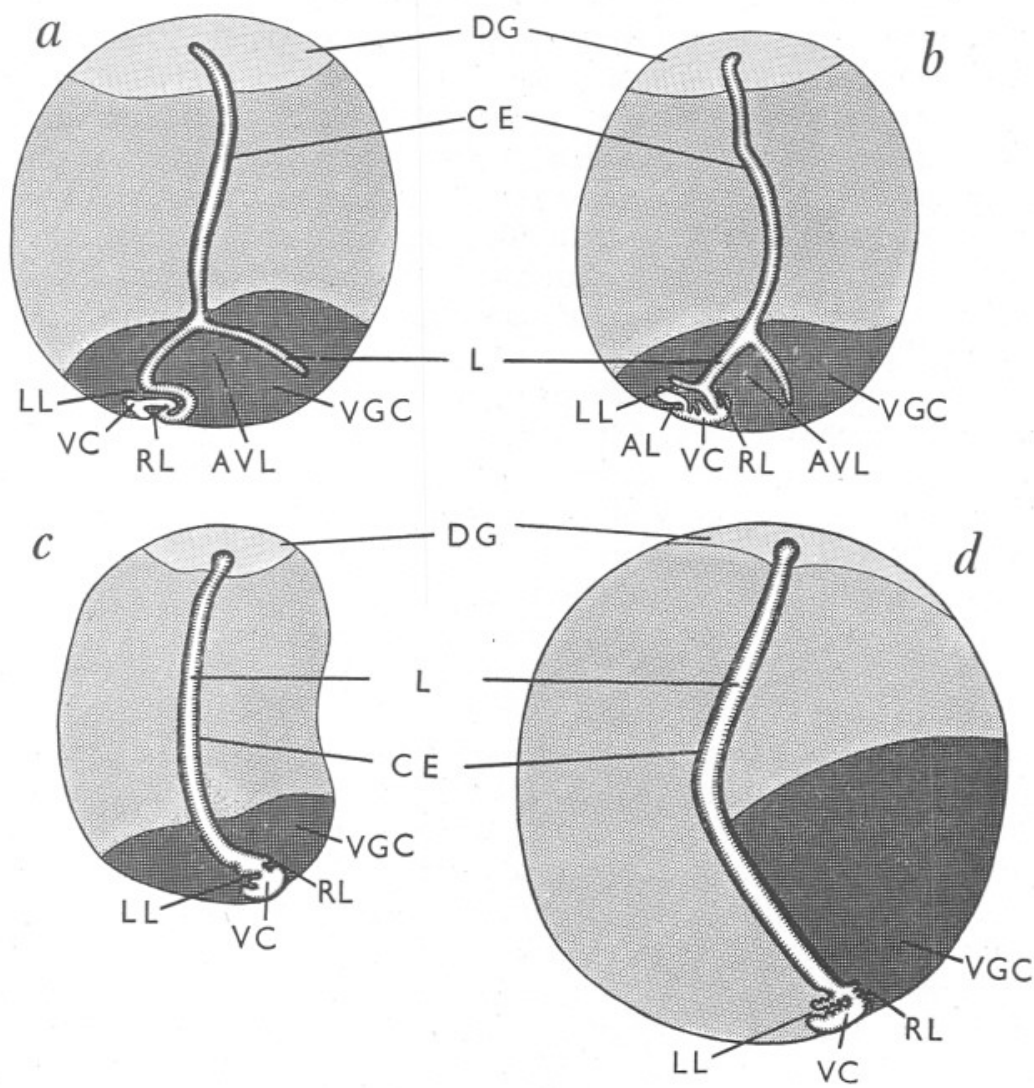

Fig. 5. Diagrammatic transverse sections through the mid region of the capsule gland.
a, Nucella lapillus ( $\times$ I4).
c, Nassarius reticulatus $(\times 23)$.
$b$, Ocenebra erinacea $(\times \mathrm{I} 7)$.
d, Buccinum undatum ( $\times \mathrm{I} 2)$.

The three types of stippling indicate corresponding glandular areas.

AL, accessory longitudinal fold; CE, ciliated epithelium; L, lumen of capsule gland; vC, ventral channel. Other letters as in Fig. 4.

its relationship to the longitudinal folds and in its role of harbouring sperm this region corresponds to the receptaculum seminis of Littorina; posteriorly, however, it opens into the ingesting gland-a brown glandular mass of tissue composed of blind tubules and having the appearance of a digestive gland. Examination of living material shows that the gland is made of only one type 
of cell (Fig. 6a), which is filled with brown spherical masses (BRM) lying in vacuoles; in the lumina of the tubules large numbers of active unorientated sperm (FS) may be present, but some may lie motionless against the free edges of the epithelium as if trapped in the protoplasm of the cells (SE). In sections it is seen that the sperms are engulfed by the gland cells and lie in vacuoles in the cytoplasm (sv). Within these they are digested and it seems probable that the products or remains of digestion impart to the gland its brown colour. A layer of connective tissue, rich in blood spaces, underlies the ingesting cells and here amoebocytes (AM) are plentiful. Many of these contain brown granules which have the appearance of excretory matter, and it is probably by this means that the gland loses waste. So far as I am aware no such gland has previously been described in the Mollusca: it is, however, present in the four species of Stenoglossa dealt with here. It appears to serve as a mechanism for ridding the animal of unwanted sperm and perhaps of deriving nourishment from them.

The lateral walls of the capsule gland attain $\mathrm{I} \cdot 75 \mathrm{~mm}$. in thickness and are composed of groups of gland cells lying at various heights and packed tightly together with a very tenuous layer of connective tissue between each group (Fig. 6b). As in the albumen gland the ducts of the cells (DGC) run parallel with one another to open between the columnar ciliated cells which line the lumen. This ciliated epithelium covers the narrow dorsal wall, under which a thin layer of gland cells is developed (Fig. $5 a, \mathrm{DG}$ ), and ventrally it spreads over the outer surfaces and free tips of the two longitudinal folds. The inner faces of these folds, forming the dorsal wall of the ventral channel (vc), are not ciliated. If the capsule gland be opened by a dorsal longitudinal incision (Fig. 4) it is seen that the right lateral wall has a ventral longitudinal cleft running from near the middle of the gland to the anterior extremity, and separating an anteroventral lobe (AVL) from the rest of this glandular area. This lobe together with two adjacent longitudinal strips of tissue-one on the right and the other on the left lateral walls-is more translucent than the surrounding areas and of a slightly yellowish hue (VGC). The lobes are composed of gland cells filled with small colourless spherules, which in sections stain lightly with iron haematoxylin and may be faintly tinged with pink by mucicarmine. After azan some spherules are reddish or orange and others blue. It would appear that two types of secretion are produced by these cells since, with azan, the final products in the lumen of the gland stain either deep orange or blue. A longitudinal area around the dorsal wall (DG) has a similar appearance in the living state. In sections of this the cells stain with iron haematoxylin and slightly with mucicarmine; after the azan stain the cytoplasm is pale blue and tiny spherules contained in it are orange in colour. With this stain the secretion is pale blue and orange, suggesting that one type of secretion is present in the cytoplasm and another in the spherules. Near the posterior end of the capsule gland two narrow transverse strips of tissue (TS), one on each side and arising near the opening of the albumen gland, separate 

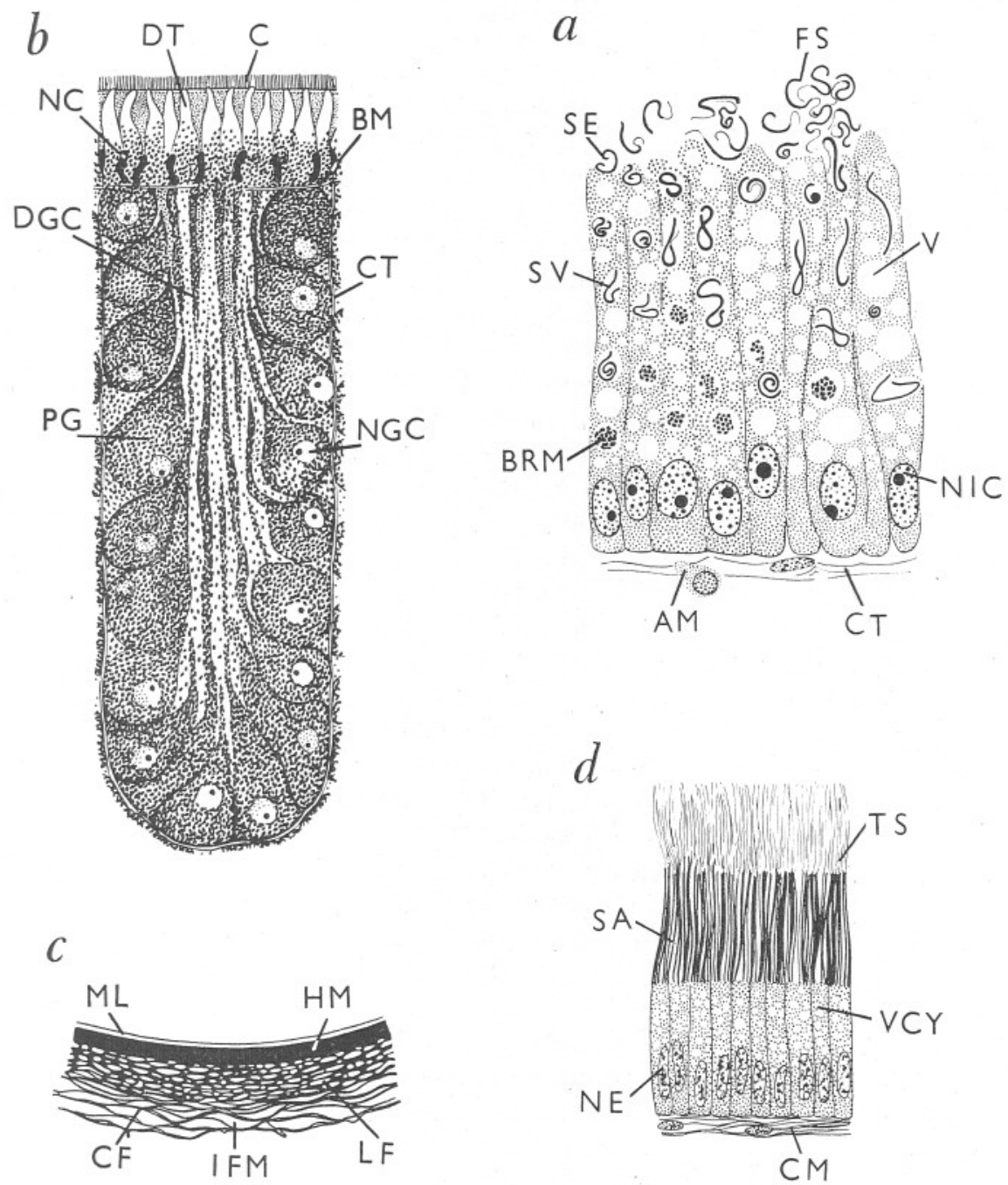

Fig. 6. Nucella lapillus. Parts of transverse sections through:

$a$, the ingesting gland, fixed in Keilin's modification of Bouin's fluid and stained in iron haematoxylin ( $\times$ about 650 ).

$b$, the wall of the capsule gland, showing a single cluster of gland cells $(\times 200)$.

$c$, the wall of an egg capsule $(\times 200)$.

$d$, the bursa copulatrix, fixed in Susa and stained in iron haematoxylin $(\times 550)$.

AM, amoebocyte; BM, basement membrane; BRM, brown spherical mass; C, cilia; CF, circular fibres; CM, circular muscles; CT, connective tissue; DGC, ducts of gland cells; DT, distal tip of duct filled with mucoid protoplasm; FS, free unorientated sperm; HM, homogeneous layer; IFM, interfibrillar mucoid substance; LF, layer of longitudinal fibres; $M L$, inner mucous layer; NC, nucleus of ciliated cell; NE, nucleus of epithelial cell; NGC, nucleus of gland cell; NIC, nucleus of ingesting cell; PG, protein secreting granules; SA, attached sperm; SE, sperm entrapped by protoplasm; SV, sperm in vacuole of cytoplasm; TS, tails of orientated sperm; v, vacuole; vcy, vacuolated cytoplasm.

In the gland cells of $b$ and in $c$, the protein secretion is shown in black and the mucoid secretion is left white. 
a right and left posterior tip (PT) from the main mass of the gland. Beneath the ciliated epithelium of the strips is a layer of circular muscles and a few muscles radiate outwards; it is this musculature which distinguishes these strips of tissue and constricts them from the surrounding wall. Both they and the posterior tips of the gland are made up of mucous cells, and similar cells border the anterior extremity of each lateral lobe (MCC). The cells constituting the main part of the gland are filled with larger colourless granules which have a rather irregular oval shape (Fig. 6b). They stain with iron haematoxylin, but are unaffected by mucicarmine; with azan they are a deep red. The protoplasm has a different staining reaction-it is very slightly affected by mucicarmine but stains deep blue with azan. The distal tip of each duct is filled with this mucoid protoplasm (DT) and no granules are visible, a fact reminiscent of the structure of the cells of the epithelium of the mammalian stomach. Again two types of secretion are produced, one a mucoid and the other a protein. Hence all the gland cells of the capsule gland, except those of the posterior tip and anterior border of each lobe, produce a double secretion and it is the intertwining of these which is responsible for the fibrous structure of the wall of the egg capsule (Fig. 6c), an appearance which is obvious if secretion be taken from the gland and examined in sea water.

A layer of dense connective tissue surrounds the capsule gland and through this run muscle fibres. The musculature is best developed beneath the ventral channel and especially near the bursa. Circular muscles surround the dorsal wall and penetrate between the gland cells. Laterally, except in the posterior transverse strips, the muscles are thinly scattered-some circular muscles run below the ciliated epithelium and in the connective tissue surrounding the gland, whilst through the thickness of the wall scattered circular and oblique fibres can be traced. The vestibule, the vagina and the bursa copulatrix are all clothed by a columnar ciliated epithelium. The walls of the bursa are thrown into folds by variations in the depth of the underlying connective tissue, and sperm may everywhere be attached to the epithelium (Fig. $6 d$ ), whilst a mass of sperm may fill the lumen. Beneath the epithelium is a thick muscular coat, consisting of an outer circular layer with longitudinal and oblique bands beneath the folds. Among the ciliated cells covering the vestibule are a few gland cells filled with spherules which stain black with iron haematoxylin and red with azan. The vestibule and vagina are extremely distensible; the walls are folded longitudinally and the arrangement of the layers of muscle is similar to that of the bursa.

The eggs are liberated from the oviduct by the relaxation of the sphincter at the entrance to the albumen gland. Here they come under the influence of ciliary currents (Fig. 4). The opposing currents drive the secretion from the epithelium and whirl it into the lumen mixing it with the eggs, and at the same time the whole mass is propelled along the gland. It then passes through the short duct which leads into the capsule gland (OAC), being drawn through by the relaxation of the circular muscles and by the action of cilia. In the capsule 
gland the forward movement of the mass of eggs is arrested whilst the wall of the capsule is secreted around it. The ciliary currents on the wall of the gland are weak. Mucus secreted by the posterior tips is directed forwards; but anterior to the tips the currents beat at right angles to the long axis of the gland-in some places away from, in others towards, the ventral channel. The currents mix and distribute the various secretions from the gland cells immediately they are poured forth into the lumen. At the anterior end of the gland the currents are directed towards the vagina (VA) and on the longitudinal folds of the ventral channel (LL, RL) they beat outwards. These folds are usually hidden from view by the overhanging glandular lobes. The passage of the egg capsule through the vestibule (v) is effected by muscular means assisted by the action of cilia beating towards the genital aperture.

\section{Ocenebra erinacea}

The female genital system of this stenoglossan is built on the same plan as that of Nucella. There are, however, the following minor differences in morphology and histology.

The gonopericardial duct appears to be wider and it opens into the pericardium by a very prominent ciliated funnel: so wide is the duct, in fact, that on relaxation of the circular muscles a mature egg may enter it. Only two types of subepithelial gland cells have been observed in the albumen gland. The more plentiful type is filled with spherules which are colourless in life, stain lightly with iron haematoxylin and are a very faint pink after mucicarmine. These cells cover the outer wall in the main part of the gland and spread on to the inner wall, where they are replaced by mucous cells, which in the posterior part of the gland, near the opening of the oviduct, completely encircle the columnar ciliated epithelium. The duct from the albumen gland opens into the ventral channel, and receives near this opening the duct from the ingesting gland. In this gland there is resorption of yolk granules as well as ingestion of spermatozoa. It is possible that these yolk granules have been derived from eggs which for some reason failed to be included in a capsule. This may also occur in Nucella, but has never actually been observed. The ventral channel (Fig. $5 b, \mathrm{vc}$ ), which is formed between the two longitudinal folds of the ventral wall of the capsule gland, is subdivided into two regions by a third longitudinal fold of tissue (AL). This arises soon after the channel emerges from the bursa and extends to the opening of the albumen gland. It lies beneath the left longitudinal fold, which completely envelops it, and in the channel formed between them the epithelium is not ciliated. Ciliated cells cover the channel between this third fold, which is not represented in Nucella, and the outer or right longitudinal fold. The albumen gland opens into the ciliated region and the transference of sperm is confined to the unciliated part.

The capsule gland is divided into the same regions as in Nucella, but there are slight variations in the types of gland cells composing the dorsal (DG) and ventral (VGC) longitudinal strips and the posterior tips of the thick 
lateral glandular lobes. The transverse strips of tissue which arise near the opening of the albumen gland, and are constricted off from the surrounding glandular areas, are made up of mucous cells. Posteriorly these are replaced by mucoid cells which often have a pink tinge. In the anteroventral lobe (AVL), separated from the right lateral lobe by a deep cleft, and in the two adjacent longitudinal strips of tissue, the cells (VGC) stain blue with azan and some spherules are reddish. These cells probably produce two types of secretion, but this is less obvious than in Nucella. The secretion in the lumen of the gland stains blue with azan and small isolated patches may be reddish or orange. The longitudinal glandular strips surrounding the narrow dorsal wall (DG) are composed for the greater part of mucoid cells, but these produce only one type of secretion and together with the anterior border of each lateral lobe stain purple when the whole gland is opened and placed in thionin. There is, however, a narrow longitudinal band of cells on each side between this dorsal strip of mucoid cells and the main part of the capsule gland which elaborates a second type of secretion, the spherules within the cells and the secretion staining bright orange with azan.

The histology of the bursa copulatrix is of some interest. If this pouch be cut open it may be seen that the white glandular walls are folded transversely and have a velvety appearance. The epithelium is composed of one type of cell, which is elongated, and the free edge is produced into a large number of stiff processes each equal to about a quarter of the total length of the cell. In the proximal half of the epithelium the cytoplasm is vacuolated, and the vacuoles contain small spherules which stain lightly with iron haematoxylin and red with azan. Distally the cytoplasm contains a mucoid substance into which the spherules migrate. The secretion in the lumen of the bursa consists of irregularly shaped mucoid masses with numerous spherules, and sperms introduced into it collect around this secretion. The nuclei of the cells of the epithelium, each with one or two nucleoli, are round or oval in outline. They lie towards the base of the cytoplasm, but migrate to the free tips of the cells when secretion is being liberated.

The musculature and the ciliary currents of the genital duct are practically identical with those described for Nucella. Here again the importance of the ciliary currents of the capsule gland appears to be in mixing and distributing the different types of secretion to form the wall of the egg case.

\section{Nassarius reticulatus}

Nassarius reticulatus resembles Nucella in the main points of the structure of this system, but differs from it in some details; these alone will be dealt with in the following paragraphs.

From the anterior end of the oviduct, near which the gonopericardial duct is given off, the laterally compressed albumen gland widens into a comparatively deep pouch, its dorsal wall being deeply convex and the ventral wall concave. The ciliary currents on the wall of the gland are similar to 
those in Nucella. The subepithelial glands are of two types only: mucous cells beneath the inner wall and mucoid cells beneath the outer. The albumen gland opens into the ventral channel of the capsule gland and near this opening receives dorsally the duct from the ingesting gland. The duct is longer than in Nucella and is somewhat coiled. The gland is less voluminous and amongst the ingesting cells which line the tubules are mucous cells. The posterior tips of the capsule gland may be brownish in colour or may have a rather transparent appearance. They are composed of mucous cells. Anteriorly each lateral lobe of the gland terminates in a reddish glandular area-during life the gland cells are filled with small orange granules. These stain deeply with iron haematoxylin and after azan the granules and the final secretion are red and the cytoplasm around the spherical basal nuclei pale blue. A transverse strip of mucous cells separates this area from the more posterior part of the gland. The right lobe is not subdivided (Fig. 5 c), and the longitudinal strips of gland cells (VGC), which border the anterior two-thirds of the ventral channel(VC) on each side and surround the dorsal end of the lumen (DG), do not produce a double secretion. The ventral strips are composed of mucoid cells and the dorsal region of mucous cells. The secreting cells, which constitute the main part of the capsule gland, contain granules of the same shape as the corresponding cells of Nucella, but they are smaller. They stain deeply with iron haematoxylin and bright orange with azan. Their secretion in the lumen of the gland has a similar staining reaction. The arrangement of the ciliary tracts on the walls of the capsule gland differs slightly from that of Nucella. The transverse currents are confined to the upper half of the gland, whilst anteriorly the currents run towards the exterior.

The ventral channel is ciliated throughout and the longitudinal folds which form its dorsal wall (LL, RL) are less pronounced than in the molluscs already described. Anteriorly the capsule gland and the ventral channel lead to the muscular vestibule which is lined by a columnar ciliated epithelium. Mucous cells are interspersed among the ciliated cells and some mucous glands lie in the connective tissue beneath the epithelium. The walls of the vestibule are thrown into deep folds. Muscles radiate from the folds to longitudinal and circular muscles which surround the whole structure. The longitudinal folds of the ventral channel arise at the anterior end of the vestibule beneath the opening of the bursa.

If the mantle cavity of Nassarius be opened the genital aperture is immediately obvious, and through it, since it is of large diameter, can be seen two further openings, one dorsal and the other ventral. The dorsal one is the aperture of the bursa copulatrix and the ventral leads to the vestibule of the oviduct. The space between the genital opening and these two inner ones thus represents the vagina. This and the bursa are covered by a columnar ciliated epithelium with an ample supply of mucous cells. The walls of the bursa are folded and beneath the epithelium is a thick muscular coat consisting of circular, oblique and longitudinal fibres. 


\section{Buccinum undatum}

The gross anatomy of the female genital system of Buccinum undatum was described by Dakin (I9I2), but many details in its structure were not observed. Of these the most outstanding are the bursa copulatrix, the ingesting and resorptive gland, and the gonopericardial duct. The general anatomy of the genital duct conforms to the typical stenoglossan plan and in many respects it approaches most closely to Nassarius reticulatus. The albumen gland assumes similar proportions. From the thin-walled oviduct it passes dorsally and enlarges to form a pouch, which is laterally compressed and opens anteriorly into the capsule gland by a wide aperture. The dorsal wall of the pouch is deeply convex and the ventral wall concave. Two types of gland cells are present-mucous cells constitute the thickness of the inner wall and spread on to the outer wall of the gland. Here, except near the opening into the oviduct, they are replaced by cells containing small spherules embedded in the vacuolated protoplasm. The spherules stain deeply with iron haematoxylin and blue with azan; after mucicarmine the protoplasm is faintly pink.

The duct from the ingesting gland opens into the dorsal wall of the genital duct at the junction of the albumen and capsule glands. The walls of the duct are deeply folded and during the breeding season numbers of orientated sperm are attached to the columnar ciliated epithelium. A thick muscular coat which surrounds the walls is chiefly composed of circular fibres, and radial muscles penetrate the folds. The duct opens into the glandular tubules, in which masses of yolk granules and unorientated spermatozoa have been observed during the months of April and May. As in Ocenebra the yolk granules and the sperm are taken up by the absorbing cells and apparently digested.

On the lateral walls of the albumen gland the cilia beat away from the narrow dorsal and ventral walls and the current is directed downwards and slightly backwards from the duct of the ingesting gland. Around the opening of the capsule gland the cilia beat posteriorly. The effect of these currents is to mix albuminous secretion with the eggs from the oviduct and probably to direct sperm from the duct of the ingesting gland and from the ventral channel on to the egg mass. Meanwhile the contents of the albumen gland are prevented from passing into the capsule gland. The musculature of the albumen gland is well developed: circular muscles lie beneath the ciliated epithelium and they are also scattered between the groups of gland cells and in the connective tissue surrounding the gland.

The right lobe of the capsule gland (Fig. $5 d$ ) is not subdivided as in Nucella and Ocenebra. After the breeding season the glandular tissue is greatly. reduced and the lateral walls may be thrown into transverse folds. The posterior tips of the gland are composed of mucous cells, and similar cells underlie the dorsal wall (DG), where they form a narrow longitudinal strip. Anteriorly each lateral lobe is bordered by mucous cells, and mucoid cells constitute the ventral half of the anterior two-thirds of the right lobe (VGC). In living tissue these areas 
can be distinguished by their slightly transparent appearance. The main mass of the gland is opaque white and is composed of one type of cell which is filled with small spherules staining deeply with iron haematoxylin and azocarmine. The ciliary currents on the walls of the capsule gland are similar to those of Nassarius.

The longitudinal folds which separate the ventral channel from the lumen of the capsule gland are less pronounced than in Nucella. The left fold (LL) is obvious on dissection and the ciliated epithelium which covers it, and the wall immediately dorsal, is thrown into longitudinal undulation by variations in the height of the cells and in the thickness of the underlying connective tissue. The right fold ( $\mathrm{RL}$ ) is represented by a number of similar though more pronounced undulations in the ciliated epithelium. Only a narrow strip of cells on the wall of the ventral channel (vC) is unciliated. Mucous cells are interspersed among the columnar cells, especially at the anterior end, and they also occur in the connective tissue beneath the epithelium. Posteriorly in the region of the transverse muscular strips the longitudinal folds terminate and the ventral channel divides into two grooves. One passes to the right and runs dorsally between the albumen and capsule glands to the duct of the resorptive and ingesting gland, and the other takes a similar course on the right side. The ciliary currents on their walls are directed towards the gland.

The muscular vestibule into which the capsule gland opens is covered by a columnar ciliated epithelium. The walls are longitudinally folded. Radial muscles are developed in the connective tissue beneath the folds and these are surrounded by a layer of circular muscles which increases in thickness towards the genital opening. The longitudinal folds of the ventral channel arise near the mid region of the vestibule and in the epithelium which covers them, and in the underlying connective tissue mucous cells are plentiful. Anterior to the origin of the folds mucous cells are distributed throughout the epithelium. Here the lumen of the vestibule is approximately circular in transverse section with a diameter of $0.5 \mathrm{~mm}$., and is surrounded by a layer of circular muscles $\mathrm{I} .25 \mathrm{~mm}$. in thickness. The vestibule and the bursa copulatrix open into the vagina. The bursa is a large and very muscular sac, dorsal in position. The walls are deeply folded and covered by a columnar unciliated epithelium which contains yellow pigment granules. Amoebocytes are found between the epithelial cells and in the lumen: they appear to act as scavengers and carry off any available prostatic secretion. Although the longitudinal folds of the ventral channel do not extend to the opening of the bursa the ventral groove runs to this point. Spermatozoa are passed from the dorsal opening of the bursa into the ventral groove and conveyed up the ventral channel of the capsule gland. The channel is surrounded by circular muscles and some longitudinal fibres, and the conduction of sperm is probably assisted by peristalsis, as in Nucella, though this has not been observed in Buccinum. The short vagina is lined by a ciliated epithelium in which no mucous cells occur. It is surrounded by a sphincter which guards the genital aperture. 


\section{The Ventral Pedal Glands}

The female Ocenebra erinacea has two ventral pedal glands. In anaesthetized animals the anterior one may sometimes be seen as a conical papilla, with a small central cavity, projecting from the surface of the foot. It lies a short distance behind the anterior pedal or pedal mucous gland in the mid line. Usually the gland is not visible. The epithelium of the papilla is very high, attaining $\mathrm{I} 80 \mu$, and is composed of ciliated cells and gland cells. The ciliated cells are narrow at the base and broaden distally; their nuclei are elongated and lie towards the upper half of the cytoplasm. The gland cells arise from the basement membrane to alternate with the ciliated cells. On fixation these glands tend to empty their secretion, leaving within the cells a granular lightly staining cytoplasm. The secretion, often entangled in the short thick layer of cilia, is black after iron haematoxylin. A second, comparatively infrequent type of gland cell is distributed in the connective tissue below the summit of the circular fold-that is around the aperture leading to the central cavity of the papilla - and in the epithelium. It contains spherules which stain deeply with azocarmine and rather lightly with iron haematoxylin. The lips are covered by a columnar ciliated epithelium, which is very low on their inner surfaces. Among the ciliated cells are a few gland cells similar to the second type of gland cell described in the gland, and these are also found in the epithelium covering the surrounding area of the foot.

The second ventral pedal gland is a short distance behind the first. It has the appearance of a pit, which in fixed material measures $2 \mathrm{~mm}$. deep and $0.6 \mathrm{~mm}$. broad and has thick glandular walls thrown into folds parallel to the surface of the foot. The lumen in transverse section is a crescentic slit with a concave anterior surface and a convex posterior surface. The pit is lined by a columnar ciliated epithelium and gland cells are scattered among the ciliated cells. These have basal nuclei and the cytoplasm is filled with small protein secretion granules. Below the epithelium is a dense layer of mucous cells grouped in clusters and in the connective tissue which separates one cluster from its neighbours are developed radial muscles. Circular and longitudinal muscles lie beneath the basement membrane of the epithelium and the ducts of the mucous cells pass between them to open into the lumen of the gland.

In the male there is a single ventral pedal gland identical in structure with the anterior one of the female.

Two ventral pedal glands are present in the female Nucella lapillus. These are comparable in position to the two glands described in female Ocenebra. In both animals the structure of the anterior gland is similar, but in Nucella it has not been seen to project from the surface of the foot, though the musculature suggests that this is possible. It communicates with the exterior by way of a ciliated duct, which has an inconspicuous external aperture lying between the circular opening of the posterior and that of the anterior pedal gland. In 
Nucella the posterior gland has the form of a deep conical pit, the walls of which may be thrown into folds running along the long axis of the walls. It is lined by a columnar ciliated epithelium, and among the ciliated cells are a few gland cells with spherules which tend to dissolve on fixation. The cytoplasm stains red with azan and lightly with iron haematoxylin. Beneath the basement membrane of the epithelium is a layer of circular and longitudinal muscles through which pass the ducts of underlying gland cells. These cells form a thinner layer than the corresponding cells in Ocenebra: in sections their cytoplasm is vacuolated and the contents of the vacuoles dissolved. The protoplasm stains blue with azan and lightly with iron haematoxylin. It is unaffected by mucicarmine or toluidin blue but the final secretion attached to the cilia and the surface of the epithelium stains lightly with these stains for mucus. Radial muscles penetrate the connective tissue of the folds and pass between the groups of subepithelial gland cells.

In the male only the anterior gland is present.

In male specimens of Nassarius reticulatus no pedal gland has been observed, but one is present in the female. It opens in the mid-ventral region of the foot a short distance behind the anterior pedal gland and resembles the posterior pedal gland of Ocenebra and Nucella. The gland forms a deep but narrow pit, broad laterally and narrow from back to front. At the dorsal end it is rounded. The walls are folded transversely and are covered by a columnar ciliated epithelium. Beneath the basement membrane of this epithelium is a layer of muscles: most of the fibres are longitudinal with respect to the pouch, but a few are circular. A layer of gland cells underlies the muscles, the cells being grouped in small clusters and their ducts passing through the muscle layer and between the ciliated cells to discharge their secretion into the lumen of the gland. After fixation in Susa the cytoplasm of the cells appears highly vacuolated, although the contents of the vacuoles have dissolved. The protoplasm stains blue with azan and lightly after iron haematoxylin; but it is not affected by mucicarmine, although the secretion in the lumen of the gland and that in some of the ducts is stained pink. It thus appears that the cells produce a mucous secretion, the precursor of the secretion not being affected by the recognized stains for mucus. Radial muscles penetrate the folds of the wall and make their way between the groups of gland cells.

The presence of a ventral pedal gland in Buccinum undatum has been denied by the majority of previous investigators. Carrière (I882) failed to find one and his results were adopted by Simroth (1907). In I910 Pelseneer confirmed Carrière's observations for both sexes, stating that the gland was present only in the embryo. Dakin (I9I2) described the anterior pedal gland (=the pedal mucous gland) and apparently failed to discover the presence of a ventral one. He obviously confused the anterior gland with the ventral and held that the former was homologous with the pedal pore, or opening of the 
ventral pedal gland, of other prosobranchs, which had once been considered as the external opening of a water vascular system. He mentioned, without any reference, that in Purpura (=Nucella) Pelseneer had ascribed to the anterior gland the function of secreting the egg capsule and concluded that in Buccinum it did the same. But in 1910-before the publication of Dakin's monograph-Pelseneer had figured both an anterior and a ventral pedal gland in Nucella, showing the egg capsule in the ventral one and had explicitly stated that the capsule was formed there. In a note to Nature Cunningham (I899) described egg capsules in the "sole gland" or ventral pedal gland of Buccinum, and so far as I know this is the only occasion on which the presence of a ventral pedal gland has been noted in this mollusc. This gland, too, was mistaken by Dakin for the anterior gland. Observations on living animals show that in male specimens there is nothing to correspond to the ventral pedal gland, but in females it can be seen as a shallow pouch some distance behind the anterior gland in the mid line.

The columnar epithelium covering the pouch is ciliated and gland cells are distributed throughout the ciliated cells. In one type of gland, which is very plentiful, the cytoplasm contains small spherules staining red or orange with azan and with varying degrees of intensity with iron haematoxylin; occasionally the spherules stain blue with azan. Mucous cells are numerous in the epithelium, and in the connective tissue below there are small irregularly shaped gland cells with contents staining deeply with iron haematoxylin; their narrow ducts penetrate the basement membrane to open between the epithelial cells. The walls of the pouch are deeply folded by variations in the thickness of the underlying connective tissue and musculature of the foot. Radial muscles penetrate the folds and external to these is a coat of circular fibres.

The whole pouch is covered with an epithelium of the same height and general histological character as is found on the neighbouring area of the foot; in the gland, however, mucous cells are fewer and the other types of gland cell are more numerous.

\section{The Egg Capsules}

The egg capsule of Nucella lapillus is an erect vase-shaped structure about $8 \mathrm{~mm}$. high. It is circular in transverse section and broadest in the middle where its diameter is about $2 \mathrm{~mm}$. At one end the capsule tapers to form a short stalk which attaches it to a basal disc, and the disc is firmly anchored by cement to the substratum. At the opposite end there is a circular aperture which is filled with a plug of a rather transparent homogeneous substance. Two longitudinal lines of thickening can be traced over the smooth surface, and these are placed so as to divide the wall into two approximately equal halves. Distally the suture of one side meets that of the other over the surface of the plug, which is thus subdivided. The minute structure of the wall has been described by Ankel (1937) who states that it consists of three layers: an 
inner layer of a homogeneous transparent substance, and middle and outer layers of fibres orientated in definite ways and separated from one another by distinct spaces. He described the inner fibres as running in a longitudinal direction and the outer fibres as being circular. Transverse sections through the wall of the capsule of Nucella (Fig. 6c) show this fibrillar appearance clearly and, if the sections be stained with azan, the three regions may be readily distinguished: the inner homogeneous layer (HM) stains red, and in the fibrous layers $(\mathrm{LF}, \mathrm{CF})$ the fibres are red, whilst the interfibrillar spaces are filled with a blue staining substance (IFM). Externally the fibrillae are more widely separated by the interfibrillar substance and are thinner. In sections stained with iron haematoxylin the inner homogeneous layer stains deeply and the fibres of the outer layers more lightly. The interfibrillar substance is hardly affected by this stain but is pink after mucicarmine. These results suggest that the wall of the capsule is composed of two substances-a protein which according to Ankel is conchiolin, and, intermixed with the protein in the outer layers, a mucous or mucoid substance. It is the distribution of these two substances which gives the fibrillar appearance to the capsule. When the capsule has weathered for some time the mucus tends to contract leaving the spaces between the fibres observed by Ankel. In the stem and in the basal disc the fibres are more irregularly disposed. The plug is made of mucus and is tightly fitted into the distal aperture of the capsule. A very thin mucous layer also covers the wall internally (ML) and is sparsely distributed over the outer surface. The capsule contains several hundred eggs embedded in an albuminous fluid, but of these only about $15-25$ hatch, the remainder being devoured by their fellows (Lebour, 1937).

The egg capsule of Ocenebra erinacea is built on the same plan as that of Nucella. It is about the same height and a narrow stalk connects it to a basal disc by which it is fixed to the substratum. The capsule is flattened on one surface and is rounded on the other, and the middle of the rounded surface may be produced into a slight keel. In transverse section it is therefore triangular. At the distal end is a circular hole blocked by a mucoid plug. Two longitudinal sutures are visible on the smooth yellowish wall, running up the centre of the convex and concave faces and continuing over the plug. Sections stained in azan show that the microscopic structure of the wall is the same as that of Nucella, the inner homogeneous layer occupying a third of the total thickness and the fibrous coats the outer two-thirds. The capsule contains from $12-20$ eggs embedded in an albuminous fluid and all may develop into young tingles (Lebour, 1937).

The laying of the egg capsule of Nassarius reticulatus has been described by Ankel (I929), and he points out the superficial resemblance between the capsule passed out from the oviduct and its more familiar form attached to the rocks or stones of the seashore. The fully formed capsule is fixed by a basal disc 
from which it enlarges into a vase-shaped structure slightly convex on one surface and flattened on the other. It is about $5 \mathrm{~mm}$. high and about $4 \mathrm{~mm}$. across at the broadest point. The walls are thinner and more transparent than in the capsules of either Nucella or Ocenebra. Examination under a binocular microscope shows that they have a fibrillar structure. The lateral margins of the flattened sides of the capsule are continued out to form a flange on each side, and this is extended over the distal end by a similar flattening of the plug. When the capsule leaves the oviduct the walls have a more opaque appearance than they have in their final state, and there are two longitudinal lines of thickening containing the material for the flanges.

Sections of capsules taken from the vestibule of the oviduct show that the wall is composed of several layers staining blue, red or orange with azan. The inner layer is a mixture of two secretions one of which stains orange and the other blue; the next is a homogeneous layer of orange-staining material and the third resembles the first. Along the longitudinal lines of thickening there is an increase in both types of secretion and the layering is ill defined. Covering the outside is a very tenuous coat of secretion which stains a bright red. Capsules collected from the shore and similarly treated show a surprisingly different structure: the wall appears to be thinner and, except in the region of the flanges, is remarkably homogeneous. It stains orange with azan, but here and there a trace of the blue secretion can be found, mainly confined to the core of the flanges. These differences between the two capsules are due to the moulding action of the ventral pedal gland.

Each capsule contains an albuminous fluid in which float up to a hundred eggs, all of which may develop into free living larvae (Lebour, I937; Portmann, I925).

The egg capsules of Buccinum undatum are laid in large masses; the lower ones of each mass are fixed to the substratum and the upper ones are piled upon them and attached to them by their bases. The bases are oval and the edges project to form flanges by which the attachment is effected. Each capsule is compressed, one side being flattened and the other convex. It is broadest at the base, which measures $12 \mathrm{~mm}$. and is about $10 \mathrm{~mm}$. in height. The flattened face is smooth, and towards the distal edge, in a subterminal position, is the oval plug, of a different appearance and consistency from the rest of the wall. The convex face is covered by numerous wrinkles which form a reticulate pattern over its surface, and the half of the flange which projects from the base of this face is similarly ridged. From each side of the oval plug a line of thickening passes to the flattened edge, the two lines representing the sutures which, in Nucella, divide the capsule into equal halves.

The structure of the wall resembles that of the capsules already described. In section it appears to be made up of four distinct layers compressed together. On the outside is a homogeneous covering and through it can be seen a coat of circular fibres, both these layers staining deeply with azocarmine and iron 
haematoxylin: the fibres are separated by a mucous secretion. Next comes a layer of similar but broader longitudinal fibres embedded in a mucoid secretion, and on the inside is a thin mucous sheet. The outer covering is spread over the surface of the plug, which, together with the base, is composed chiefly of mucus.

The egg case contains several hundred eggs embedded in albumen; out of these only about ten come to maturity, the rest being used as food (Portmann, I925).

\section{The Function of the Female Genital Duct and of the Ventral Pedal Gland}

\section{Nucella lapillus}

At the time of copulation the male passes the penis through the female genital aperture so that the tip is directed into the bursa copulatrix. Spermatozoa are released into this pouch and attach themselves to the epithelial cells by their heads; these orientated sperms lie closely packed side by side with their tails pointing into the lumen of the bursa, in which unorientated sperm may also lie. After copulation the spermatozoa may be passed up the ventral channel of the uterus by peristalsis, assisted perhaps by their own activity, and they may become attached to the epithelium of the channel or of the duct of the ingesting gland. It is not known how soon after copulation the formation of the egg capsules begins, but evidence suggests that at least on some occasions the two events follow closely upon one another. Several specimens of Nucella will often be found associated with a batch of egg capsules: some of these are usually males and others females, and whilst some females may be copulating others will be laying eggs.

The method by which the capsule is manufactured by the genital duct may be partly deduced from the observations given above and verified by the study of living animals. A large number of eggs are passed down the oviduct into the albumen gland and here they are mixed by ciliary activity with the albuminous secretion. At such a time the walls of the gland are greatly distended by the mass of eggs. The exact locus of fertilization is uncertain: if sperms from the ventral channel and the duct of the ingesting gland are passed into the albumen gland on the relaxation of the sphincter muscle which guards its opening, then fertilization will occur in the lumen of this gland. Otherwise spermatozoa may be poured on to the eggs as they enter the capsule gland.

The mass of albumen and eggs is passed into the capsule gland by muscular assisted by ciliary action, and here the process of capsule formation begins. Only on one occasion has a capsule been found within the gland, although numerous specimens have been examined in the hope of finding capsules in various stages of formation. In this case the capsule was near completion and occupied the whole length of the gland, the plug being at the upper end, near the posterior mucous tips, and the base anterior. The longitudinal sutures which divide the capsule into two halves were lying one against the ventral 
channel and the other against the narrow dorsal wall. The wall of the capsule was not so smooth as in its final form, nor was it so completely circular in transverse section. The longitudinal sutures were more obvious and the basal disc was represented by a rather irregular fibrous mass. From the orientation of this capsule may be deduced the functions of the various regions of the gland. Since the plug is composed of mucus it is apparently secreted by the posterior mucous tips and the capsule wall by the rest of the gland. As already stated the wall of the capsule is made of three layers: the innermost is composed of a homogeneous substance which stains an orange-red with azan and black with iron haematoxylin, is similar to the more plentiful secretion from the cells of the main part of the capsule gland, and also resembles the non-mucoid secretion from the cells of the dorsal wall and those which border the greater part of the ventral channel-it is therefore presumably derived from them. Outside this layer is a double fibrous coat formed by intermingling this same protein secretion with a mucoid substance. The way in which this occurs and the manner of formation of the egg case as a whole may be reconstructed as follows.

Prior to the entry of the secretion and eggs from the albumen gland the cavity of the capsule gland becomes filled with a mass of secretion from the gland cells in its walls. These secrete first the protein matter and then, in increasing quantities, the mucoid substance which they produce, and the result is that the lumen is filled with a mass of secretion which is almost pure protein in the centre but consists, in its outer layers, of an emulsion in which the mucoid material acts as a dispersed phase in a continuous phase of protein. Because of the steadily increasing quantity of mucus and of the accompanying decrease in the production of protein the size of the mucoid droplets steadily increases from the centre to the periphery of the mass, and the strands of protein which separate the drops gradually decrease in size. The predominantly transverse direction of the ciliary currents on the walls of the gland rotates the mass and draws out the drops of mucoid material into streaks parallel to the transverse axis of the gland, and the protein material separating them is drawn out into strands elongated in the same direction. When the duct between the albumen and the capsule glands is opened, the albumen and the eggs are forcibly passed into the central portions of the secretion lying in the latter, so as to invaginate this into a vase-shaped structure with a round hole at the inner end into which the plug will later be fitted. This process of invagination deposits the eggs and their accompanying albumen in the centre of the mass of secretion occupying the capsule gland, which is composed of unmixed protein material, and from this is formed the innermost layer of the capsule. It has also the effect of drawing the outer emulsion of protein and mucoid secretion into sheets around the inner homogeneous layer, in which the direction of elongation of the mucoid droplets now lies parallel to the direction of movement of the eggs, that is, parallel to the long axis of the gland: from this results the longitudinal direction of the strands of the inner part of the fibrous coat. The outer part of this layer, being still 
exposed to the ciliary currents on the wall of the gland, retains the original alignment of the drops and so gives rise to the outer part of the fibrous coat in which the fibres are circular in direction. With the disappearance, on exposure, of the mucous dispersed phase the space occupied by it is left as a series of lacunae separating what now appear as strands of fibrous material. The mucus which lines the wall internally is secretion from the posterior tips, which was dragged along with the mass of eggs when the latter passed into the capsule gland. These tips continue to pour out secretion while the wall of the capsule is being elaborated by the more anterior parts of the genital duct. The mucus forms an accumulation which is fitted into the hole in the upper part of the capsule by the muscular action of the transverse strips which border the mucous tips anteriorly. These press the upper edge of the wall of the capsule on to the mass of mucus so that the cavity within is securely closed. The suture which divides the plug into two equal halves demarcates the limit of the secretion produced by each posterior tip.

The egg capsules are passed from the oviduct to the posterior ventral pedal gland along a groove situated in the right anterior portion of the foot and temporarily formed for that purpose. When examined in this position, it can be seen that the gland fits tightly over the capsule, and only the tip of the basal disc is protruded from the sole of the foot. The wall of the capsule is compressed and moulded to the final, smooth, vase-shaped outline. The stalk is constricted from the basal disc and the latter finally pressed out and fixed to the substratum. The mucous secretion from the subepithelial cells of the gland acts as a lubricant during the fashioning of the egg case. Secretion from the second type of gland cell may have a similar function, or may, in some way, be concerned with the hardening of the wall.

The anterior ventral pedal gland is equally developed in both sexes. Its function is obscure. Since, however, a corresponding gland is present in Ocenebra erinacea and both animals are carnivorous feeders, obtaining their food by boring the shells of other molluscs, it is possible that the gland may be concerned with their specialized feeding mechanism (Graham, I94I).

\section{Ocenebra erinacea}

Since the structure of the female genital duct of this mollusc and of the egg capsules produced by it so closely resembles those of Nucella lapillus, it may be concluded that the mode of functioning of the system is similar in the two animals.

The shape of the completed egg capsule of Ocenebra differs from that of Nucella, and this is due to a difference in the shape of the ventral pedal gland which moulds it. In the former the capsule is much more drastically changed by this gland than in Nucella. In the final state the two longitudinal sutures which are formed in the genital duct are situated one in the middle of the concave surface and the other in the middle of the convex. From this it may be deduced that the orientation of the capsules in the pedal gland must always be the same. 


\section{Nassarius reticulatus}

The functioning of the female genital ducts of Nassarius agrees with that of Nucella, but there are some differences in the structure of the capsule which need explanation. When the capsule is being formed it does not occupy the whole length of the capsule gland, with the effect that as it passes outwards successive layers of secretion are poured over it. The plug is formed by the posterior mucous tips and the wall is moulded around the plug by the transverse muscular strips. Anterior to these the ciliary currents beat at right angles to the long axis of the gland, and they mix the mucous and mucoid secretions from the cells overlying the dorsal wall and bordering the ventral channel with that from the rest of the gland. In this way the inner layer of the capsule wall is formed. Over the anterior part of the gland the ciliary currents are directed forwards and there is little mixing of the secretion. That produced by the mucous or mucoid secreting cells is mainly confined to the dorsal and ventral lines of thickening, whilst the homogeneous secretion from the rest of the gland forms the second layer of the wall. Mucus is then mixed with this secretion as the capsule is passed to the anterior tips of the gland, since these are bordered posteriorly by a strip of mucous cells. Finally the anterior tips coat the wall with yet another thin layer which stains deeply with azocarmine and iron haematoxylin. The muscular vestibule then expands to receive the capsule and it is passed to the genital aperture. At this stage the case is biconvex and two longitudinal lines of thickening extend from the plug to the thick basal plate. The capsule is directed to the ventral pedal gland along a groove in the foot, and here a mucoid secretion is poured upon it which may act not only as a lubricant but as a hardening mixture. The walls are compressed and the flanges are formed from the longitudinal lines of thickening. At the same time the basal disc is constricted from the capsule, which assumes its final flattened shape in correspondence with that of the lumen of the pedal gland.

\section{Buccinum undatum}

Some knowledge of the functioning of the female ducts of Buccinum has been obtained by studying specimens during the process of egg laying and also by dissecting such animals. Unfortunately only one capsule, and that fully formed, was found still within the oviduct. This differed in several respects from the finished cases which are fastened to the rocks on the shore. The capsule was broadly oval in shape and its surface was smooth; the plug occupied an approximately terminal position and the fins around the base were thicker. Microscopically the walls were more loosely compacted.

On leaving the genital duct such a capsule is passed along a temporary groove of the foot, which runs from near the genital aperture to the ventral pedal gland. Within the latter it is retained for several minutes and is meanwhile kneaded by the pedal musculature which flattens the capsule and stamps 
the reticulate pattern on to the convex face. The flanges are compressed and anchored to the substratum.

The manner in which the four layers making up the wall of the capsule are laid down around the mass of eggs appears to be as follows. The three inner layers are similar to the layers of the capsule wall in Nucella and are formed in a corresponding manner except that the secretion is derived from the upper part of the gland only-the capsule occupying only about half the total length of the gland during its formation. Whilst this secretion is taking place a mass of mucoid and protein material is produced from the walls of the whole lower section of the gland. On the completion of the formation of the wall of the capsule in the upper half, the capsule is pushed against this material, which is thus collected into a heap situated at the base of the capsule-in this way the material for the basal disc and its flanges is brought into its correct position in relation to the rest of the wall of the egg case, and even at this stage the rudimentary basal disc and flanges can be separately discerned in it. When the capsule is pushed through the lower half of the gland, collecting the material for its base as it goes, a second period of secretion is initiated and a layer of almost pure protein secretion is applied over the àlready formed walls and also over the top of the plug embedded in them.

\section{Discussion}

In the majority of the British Stenoglossa the development of which has been studied, there is complete suppression of the free living larval stage, the young emerging from the capsule as a miniature of the adult. In some of them, however, such as Nassarius, the capsule contains up to a hundred eggs and these develop into planktonic larvae. In Ocenebra about a fifth of this number of eggs is present in one capsule and there is sufficient nourishment for all to develop as far as the crawling stage. The newly laid egg capsules of Nucella and of Buccinum undatum contain several hundreds of eggs, but the supply of nourishment within any one capsule is insufficient for all the eggs to complete development, and, as a result, the most precociously developed embryos feed on the less advanced. In Littorina (Linke, 1933) and the majority of other prosobranchs each egg is surrounded by its own supply of nutrient albumen with which it is encased in a protective shell: it is the loss of this individual shell-uniting all the eggs in a common chamber-which has permitted the evolution of embryonic cannibalism in the Stenoglossa and has, among other factors, contributed to the suppression of a free larval stage.

The egg capsules of the Stenoglossa which have been investigated are very similar in structure. The variations in shape are due not to any fundamental differences in the structure of the genital ducts themselves, but to differences in the shape of the ventral pedal gland which moulds the capsules passed to it in an unfinished condition from the capsule gland. The wall of the capsule is highly elastic and has a fibrillar appearance due to the mixing together of the various secretions from the capsule gland. One end is anchored to the 
substratum and at the opposite end is a circular aperture in the wall which is filled by a mucous or mucoid plug. Ankel (1937) has shown that in Nucella this plug is dissolved by the young animals when they are ready to hatch, and it is probable that in the other species the animals have a similar means of escape, for in empty, discarded, capsules the wall is always intact and the plug gone.

The ingesting and resorptive gland of the female genital system is one of the more interesting features which call for discussion. The phenomenon of sperm and yolk ingestion does not appear to have been previously described in the Mollusca, although the ingestion of sperm has been demonstrated in other invertebrate phyla. In the bed bug, Cimex, Abraham (1934) has shown that the majority of sperms in the female are normally absorbed in the "Resorptionsorgane", previously known as the spermatheca (Cragg, I923). Here they become motionless and disappear. Sperms are also taken up by leucocytes as they traverse the haemocoel on their way from the body wall to the genital tract. In Peripatopsis (Manton, 1938) there is no special sperm ingesting organ, but absorption takes place in the ovary and the sperm provides the ova with some of the nutriment necessary for growth. In both these instances there appears to be some special significance attached to the process, for it has been suggested that the normal development of the ova is dependent on sperm absorption (Cragg, I923; Manton, I938). Copulation is of frequent occurrence in both animals. An ingesting gland is well developed in Nucella lapillus, an animal in which copulation and capsule formation continue throughout the year; examination shows that an excess of sperm is often present in the female, whilst the frequency with which copulating pairs can be collected suggests that copulation is frequent in this species too. The excess sperms are absorbed as previously described, but whether the development of eggs to maturity is in any way dependent upon the amount of sperm absorbed, or whether absorption is merely to empty the ducts of unwanted sperm, is as yet unknown. In Nassarius reticulatus the gland is smaller and probably of less importance in the functioning of the reproductive system. Specimens of Buccinum which were collected and sectioned during April show that the number of sperms in the gland is small as compared with the quantity of yolk present. During the breeding season the sperms in the genital duct of a female Buccinum are comparatively fewer than in Nucella and consequently the need for sperm ingestion may be less. The gland, however, is not reduced in size, since a second task-that of resorbing unused yolk granules-has been imposed upon it. This yolk must originate from eggs which for some reason are not included in a capsule. In Ocenebra during the breeding season yolk has also been found in the lumen of the gland and in the resorptive cells, but not in such quantities as in Buccinum. Yolk resorption may occur in Nucella and Nassarius, but has never been observed.

In the male system there is also a means of resorbing sperm. In the vesicula seminalis the epithelial cells frequently contain sperm in various stages of 
digestion. Linke (1933) observed this in Littorina and stated that the process continued during the whole period of sexual activity. This suggests that the production of sperm by the testis may be in excess of requirements, or that too great a number of sperms in the seminal vesicle may in some way upset the functioning of the system. The cells may have the ability of resorbing only senile sperm (though the presence of senile sperm so close to the testis seems improbable) and thus by a selective mechanism maintain within the duct an effective stock, or the absorption may be haphazard with the intention of safeguarding the duct against blockage. In neither male nor female is the ingestion of sperm restricted to that of apyrene spermatozoa: in both sexes, where two kinds do occur, each type is ingested.

The opening of the prostate into the mantle cavity is another character of the male genital system which needs some comment. In Littorina the male duct, anterior to the opening of the vas deferens into the prostate, is open throughout its length. The lower Stenoglossa, Nucella and Ocenebra, show evidence of the method by which this duct was closed during the course of evolution, but in them the closure is incomplete at one point, and a slit-like communication with the posterior end of the mantle cavity remains-in Ocenebra this is of quite considerable size. The cilia which direct the sperm through the prostate beat away from this opening and during the actual transference of sperm to the female there is no leakage into the mantle cavity. In Nassarius and Buccinum, in which the prostate is in the form of a narrow and highly muscular duct, there is an opening in a corresponding position, but it lies at the end of a short duct which leads from the prostate to the mantle cavity. In Buccinum the opening of the vas deferens into the prostate is well in front of this duct, so that normally the sperm, which is rapidly passed forward by peristalsis, is prevented from escaping. Although there is an evolutionary trend towards the complete closure of the male duct the persistence of the opening in these higher forms at once suggests that it plays some important role. It is conceivable that it functions as a safety valve, for if during the act of copulation the male is disturbed and forced to withdraw within its shell, sperm distending the prostate would be enabled to escape into the mantle cavity, so reducing the pressure in the gland and facilitating a more speedy withdrawal to safety. There is no evidence that excess sperm liberated from the vas deferens is at any time absorbed by the cells lining the more anterior regions of the male duct; it may be that it is always released to the mantle cavity. On one occasion when the shell of a male Buccinum was removed by bone forceps sperm was actually seen to escape in this way.

In the female the gonopericardial duct opens at the junction of the oviduct with the albumen gland. It is found in a comparable position in female Littorina. In the Stenoglossa and Littorina it is absent in the male, as also in Calyptraea sinensis and Crepidula unguiformis (Giese, I915). In the mature male of Ocenebra erinacea there is evidence of its previous existence in the presence of a short diverticulum given off from the vas deferens and connected 
to a prominence on the pericardial wall by a band of dense connective tissue and muscle fibres. In Littorina there is no diverticulum, but a similar strip of connective tissue is developed. Linke (1933) suggests that the persistence of this duct in the female is connected with the fact that the eggs are too large to pass through it, and that it has been abolished in the male to prevent sperm escaping. This may explain its distribution in the Stenoglossa, but in Ocenebra sections of the duct show that its dimensions when the muscles are relaxed would allow the passage of eggs, and in one specimen of Buccinum, which admittedly was under abnormal conditions (affected by the strain of having the shell removed), eggs were seen to pass from the oviduct to the pericardial cavity.

The gross structure of the male genital systems of the stenoglossan prosobranchs described here agrees in yet other respects with that of the male systems of the above-mentioned mesogastropods. In Calyptraea, Crepidula and Capulus (Giese, I915), and in the three species of Littorina described by Linke (1933), the upper part of the vas deferens functions as a seminal vesicle, and from this, during copulation, sperm is liberated to the true vas deferens, a short ciliated duct. In all of these molluscs, however, the seminal duct anterior to the vas deferens is represented by an open groove. A bilobed prostate is developed in Littorina and this is homologous with the prostate of the Stenoglossa.

So far as the female is concerned the genital systems of the Mesogastropoda and the Stenoglossa conform to the same fundamental plan-a narrow proximal oviduct opening into a wide glandular distal section with a spermatheca lying near the point of junction. It may be pointed out that the male tract can be split into the same two divisions and, with the exception of the males of Nassarius and Buccinum, the thickening of the walls of the glandular parts in both sexes is restricted to the lateral walls, leaving narrow dorsal and ventral areas where few glands occur. In animals with an open genital groove the dorsal area appears as a groove separating the right and left glandular lobes, along the free edges of which runs on each side a thinner marginal strip, representing the ventral areas. When fusion of the lips of the groove has converted it into a closed tube the former persists as the narrow dorsal wall of either the prostate or capsule gland, and the two latter join one another to form the ventral channel. In the mesogastropods the receptaculum seminis is situated at the posterior end of the glandular uterus; in Littorina it is in the form of a small pouch embedded in the albumen gland; in Calyptraea and Crepidula it is represented by a number of blind tubules. No mention is made of any sperm-ingesting epithelium in these snails, so that there would appear to be no method of utilizing the waste genital products. The ingesting gland of the Stenoglossa occupies a comparable position and is homologous with the receptaculum-the duct of the gland still functions as an area for the storage of spermatozoa, but at its distal end a large number of glandular tubules are developed and in the walls of these sperm and also yolk granules may be digested. 
The various types of gland cells of the thick-walled uterus are in each genus mapped out according to a definite plan. In Calyptraea the cells are of three types: some pour a fibrous secretion over the eggs, which may be similar to the conchiolin from the capsule gland of the Stenoglossa, and others are mucous cells. Giese was unable to trace the various types of secretion in the fully formed capsules. In Littorina the albumen gland occupies a posterior position. It is homologous with that of the Stenoglossa, and fertilization occurs in both within the lumen of the gland. The fertilized eggs of Littorina, each coated with albumen, pass next to the shell gland, a structure which is not developed in the Stenoglossa, for in them the individual eggs are not enclosed in a shell, but lie freely in a common mass of albuminous secretion. In $L$. littorea and L. obtusata the jelly gland, which lies anterior to the shell gland, is homologous with the capsule gland of the Stenoglossa. In L. rudis the jelly gland has been modified to form a brood pouch in which the embryos develop into miniature adults. Whereas in the Stenoglossa the wall of the capsule is secreted around the egg mass in the capsule gland, Linke states that in L. littorea the jelly gland secretes a gelatinous fluid around the eggs, which have already been enclosed in a shell, and that the outer wall of the egg case is formed in and moulded by the ovipositor, which is situated on the right side of the head. The wall is tough and shows spiral markings. Sections of the jelly gland of this species show that it is made up of cells producing a protein secretion and of some mucous cells-hence in histological structure it resembles the capsule gland. In the Stenoglossa there is no definite structure to which the name ovipositor may be applied, but the same region at the right side of the head passes the capsule to the ventral pedal gland and so may be regarded to some extent as its homologue. The ventral pedal gland takes over the task of moulding the capsule. A bursa copulatrix lies at the anterior end of the jelly gland in Littorina and sperms are conducted from this pouch to the receptaculum by way of two longitudinal folds: these are ciliated and the sperm travels beneath them in the direction of the ciliary currents. In the Stenoglossa similar longitudinal folds separate a ventral channel from the lumen of the capsule gland, and along this the sperms are passed by peristalsis, assisted by their own activity, to the duct of the ingesting organ. No bursa is developed in Calyptraea, Capulus or Crepidula, for in each of them the penis deposits the sperm directly into the receptaculum.

So far as the interrelationships of the various gastropods dealt with in this paper are concerned, the conclusions which can be drawn from the comparative structure and function of the reproductive system are the same as have been arrived at by a study of other systems-that Nucella and Ocenebra belong to a more primitive group than Buccinum and Nassarius. This is seen particularly clearly in the persistence of indications of an open male duct in the two former genera, and, in Ocenebra, in the presence of a well-formed vestige of a gonopericardial duct in the male. In other respects the two groups appear to have attained a very close degree of similarity and this extends even to the habit of embryonic cannibalism. Since some members of each group 
have this habit and others have not this must be an example of parallel evolution.

Nassarius appears to have retained a primitive feature in still possessing a free-swimming veliger, although in other respects, such as the ventral pedal gland, it appears to be less primitive than Buccinum, but the gland in the latter may owe its primitive structure to degeneration. The other members of the group have sacrificed the benefit of wider distribution conferred by free larvae for the greater certainty of the young developing to a crawling stage and of reaching the correct habitat for adult life; this is ensured, first by the provision of eggs as food for the precociously developing embryos, and secondly by the fixation of the capsules on the shore in a suitable position for the young snails to start independent life.

So far as the remaining groups of the Stenoglossa, with the exception of the Toxoglossa, are concerned, little in the way of comparison can be made. The Volutacea include a large number of mollusca of the anatomy of which very little is known. The work of Küttler (I9I3) on Oliva indicates that there is a close similarity between this animal and the Buccinacea. In the Volutids, on the other hand, the brief note by Woodward (I9OI) would suggest that the conditions of the male genital tract are rather more primitive than occur elsewhere in the Stenoglossa, since he describes an open seminal groove running across the mantle cavity and along the penis. The description is too short to allow one to decide whether the condition resembles that found in Calyptraea or that in Nucella.

Taking all into consideration, however, the fact remains that the Stenoglossa are a highly specialized group of prosobranchs. This can be seen not only in the highly modified genital system, in the specialization of the egg case and embryonic mode of life, but also in the structure of the nervous system (Bouvier, I887), in the elongation of the proboscis (Amaudrut, I898) and in the complexity of the oesophagus (Graham, I94I).

\section{SUMMARY}

The foregoing pages include an account of the anatomy and histology of the male and female genital ducts of Ocenebra erinacea, Nucella lapillus, Nassarius reticulatus and Buccinum undatum. Observations have also been made on the mode of functioning of the ducts and the formation of the egg capsules.

In both male and female it is possible to divide the genital ducts into a narrow and thin-walled proximal section which leads from the gonad and opens into a thick-walled glandular distal region, and in this respect the Stenoglossa agree with the mesogastropods. Near the junction of these two portions, in the female, arises the gonopericardial duct, which puts the genital duct into communication with the pericardial cavity; in males this structure is lost or reduced to a vestige lying in a similar position. 
In males the upper part of the proximal region of the genital duct is used as a vesicula seminalis and the epithelium is capable of taking up and digesting effete or superfluous sperm. Sperms are passed from it into the anterior, distal region during the act of copulation, and secretion from the glands is mixed with them and provides the medium in which they are transferred to the female. In Ocenebra and Nucella this glandular region, the prostate, extends only as far as the opening of the mantle cavity, from which a continuation of the duct, without glandular walls, runs to the penis. The entire distal half of the male duct shows evidence of having been derived from an open seminal groove such as is found in Littorina. The transformation is incomplete at the posterior end, where the prostate opens directly to the mantle cavity. In Nassarius and Buccinum the prostate extends to the base of the penis and there is a similar communication in the form of a narrow duct. In all the species, seminal fluid may, if necessary, be lost through this opening.

In females the whole of the proximal part of the oviduct serves to carry eggs from the ovary to the glandular distal section, a sphincter preventing their entry into the gonopericardial duct. The distal region may be divided into (i) the albumen gland; (ii) the capsule gland; (iii) the vestibule; (iv) the vagina; (v) between the albumen and capsule glands, the spermatheca, and (vi) the bursa copulatrix.

The albumen gland produces an albuminous fluid by which the eggs are surrounded, and fertilization occurs in this region. The capsule gland secretes around the mass of eggs and albumen the walls of the egg case composed of mixed protein and mucoid materials, the process of capsule formation being described in detail. The plug, of mucus, is produced by localized regions of the gland, the posterior mucous tips, and is moulded into position in the capsule by special muscular strips. The bursa copulatrix receives the seminal fluid from the male in copulation. The sperm becomes attached to the walls and, in Buccinum at least, the prostatic secretion is absorbed by amoebocytes. Later the sperms migrate, partly by their own activity, partly by muscular or ciliary action on the part of the female, along the ventral channel of the capsule gland to the spermatheca. They are stored here by being attached to the wall until required, and some storage may also occur in the upper end of the ventral channel. The spermatheca is provided with several tubular outgrowths distally, and in these ingestion and destruction of superfluous spermatozoa occur. In Ocenebra and Buccinum, and probably in the two others as well, a resorption of stray particles of yolk occurs in the same epithelium. No connexion between this and the maturation of the eggs has been noticed, nor is the ingestion limited to apyrene spermatozoa. No shell gland is present and the eggs are therefore enclosed in a common mass of albumen, a fact which permits of embryonic cannibalism.

The egg capsules, roughly formed by the glands at the base of the oviduct, are passed along a temporary groove on the right side of the foot, perhaps 
homologous with the ovipositor of mesogastropods, to the ventral pedal gland in the middle of the sole of the foot. Here they are manipulated into their definitive shape, their walls are hardened and they are cemented to the substratum. The gland occurs in females only. In both sexes in Ocenebra and Nucella a second ventral pedal gland of obscure function lies directly in front of it.

The relationships of the Stenoglossa amongst themselves and with the lower gastropods are discussed.

\section{REFERENCES}

Abraham, R., I934. Das Verhalten der Spermien in der weiblichen Bettwanze (Cimex lectularius L.) und der Verbleib der überschüssigen Spermamasse. Z. Parasitenk., Vol. vI, 559-9I.

Amaudrut, A., I898. La Partie antérieure du tube digestif et la torsion chez les gastéropodes. Ann. Sci. nat. (Zool.), ser. 8, Vol. vII, I-29I.

ANKEL, W. E., I929. UUber die Bildung der Eikapsel bei Nassa-Arten. Verh. Dtsch. zool. Ges., Vol. xxxirI, Zool. Anz., suppl. Iv, 219-30.

- 1935. Das Gelege von Lamellaria perspicua L. Z. Morph. Ökol. Tiere, Vol. xxx, $635-47$.

— I937. Der feinere Bau des Kokons der Purpurschnecke Nucella lapillus (L.) und seine Bedeutung für das Laichleben. Verh. Dtsch. zool. Ges., Vol. xxxix, Zool. Anz., suppl. x, 77-86.

Annandale, N. \& Sewell, R. B. S., I92I. The Banded Pond-snail of India (Viviparus bengalensis). Rec. Indian Mus., Vol. xxir, 215-92.

BouvIER, E.-L., I887. Système nerveux, Morphologie générale et Classification des Gastéropodes prosobranches. Ann. Sci. nat. (Zool.), ser. 7, Vol. III, I-5IO.

CARrIÈRE, J., I882. Die Fussdrüsen der Prosobranchier und das WassergefässSystem der Lamellibranchier und Gastropoden. Arch. mikr. Anat., Vol. xxI, 387-467.

CRAGG, F. W., 1923. Observations on the bionomics of the bed bug, Cimex lectularius L. Indian fourn. Med. Res., Vol. xI, 449-73.

Cunningham, J. T., I899. Formation of egg-capsules in Gastropoda. Nature, London, Vol. LIX, 557.

Dakin, W. J., I9I2. Buccinum (The Whelk). L.M.B.C. Memoir. London, Williams and Norgate.

GIEse, M., I915. Der Genitalapparat von Calyptraea sinensis Linn., Crepidula unguiformis Lam. und Capulus hungaricus Lam. Z. wiss. Zool., Vol. cxiv, I69-23I.

Graham, A., I94I. The oesophagus of the stenoglossan prosobranchs. Proc. Roy. Soc. Edin., B, Vol. LXI, I-22.

HalleR, B., I888. Die Morphologie der Prosobranchier gesammelt auf einer Erdumsegelung durch die königl. italienische Korvette "Vettor Pisani". I. Morph. Fb., Vol. XIV, 54-169.

KeIlIN, D., I92I. On the pharyngeal or salivary gland of the earthworm. Quart. Fourn. Micr. Sci., Vol. Lxv, 33-6r.

KÜTtleR, A., I9I3. Die Anatomie von Oliva peruviana Lamarck. Zool. fb., suppl. xIII (Fauna chilensis, IV), 477-544.

Lebour, M. V., I937. The eggs and larvae of the British Prosobranchs. Fourn. Mar. Biol. Assoc. U.K., Vol. xxII, I05-66.

LINKE, O., I933. Morphologie und Physiologie des Genitalsapparates des Nordseelittorinen. Wiss. Meeresuntersuch., Vol. xIx, 5, $60 \mathrm{pp}$. 
Manton, S. M., I938. Studies on the Onychophora. IV. The passage of spermatozoa into the ovary of Peripatopsis and the early development of the ova. Philos. Trans. Roy. Soc., B, Vol. cCxxviII, 42I-4I.

PelseneER, P., I9IO. Glandes pédieuses et Coques ovigères des Gastéropodes. Bull. Sci. Fr. Belg., Vol. xLIV, I-9.

1926. Notes d'Embryologie malacologique. Bull. Biol., Vol. Lx, 88-I I2.

PortmanN, A., I925. Der Einfluss der Nähreier auf die Larvenentwicklung von Buccinum und Purpura. Z. Morph. Ökol. Tiere, Vol. III, 526-4I.

Simroth, H., I896-1907. Gastropoda Prosobranchia, in Bronn, H. G.: Klassen und Ordnungen des Tierreichs, Vol. III. Leipzig: Akademische Verlagsgesellschaft.

ThIele, J., I925. Gastropoda Prosobranchia, in Kükenthal, W. and Krumbach, T.: Handbuch der Zoologie, Vol. v. Berlin: de Gruyter.

WINCKWORTH, R., I932. The British Marine Mollusca. Fourn. Conch., Vol. xIx, 2 I I-52.

WooDWARD, M. F., I90I. Note on the Anatomy of Voluta ancilla (Sol.), Neptuneopsis gilchristi Sby., and Volutilithes abyssicola (Ad. and Rve.). Proc. Malacol. Soc. Lond., Vol. IV, II7-25. 